\title{
Civilizing the Slavic Muslims of Bosnia-Herzegovina
}

\begin{abstract}
Although in almost every European state women have for many years been allowed and encouraged to study at university, and female physicians are nothing new, especially for women's and children's diseases, the Austro-Hungarian government has outrun all other empires and countries by appointing the first female state physician on this continent and by installing her in this important office in the same genuine and binding way in which state officials are generally appointed. It is a Slavic land that has been designated as the place where the first female state physician is to work, and it is three times the pleasure for us that she is our countrywoman, like us in her opinion and spiritual outlook, a noble-minded and highly educated patriot, Miss Anna Bayerová, MD, from Bern, known to our readers, if not otherwise, from previous years as a spirited contributor to our paper. We shall keep in festive memory the date on which the Austro-Hungarian state appointed this graceful-minded Slavic woman as the most desired assistant of her Slavic sisters, the Mohammedan Serbs in Bosnia, protector of their physical health and moral sensitivity.
\end{abstract}

ŽENSKÉ LISTY, $1892^{1}$

On January 8, 1892, in the Bosnian city of Tuzla, for the first time ever in history a Czech woman swore before government officials the solemn oath that would allow her to become a physician in the service of the Austro-Hungarian state. The paradox of a government that did not allow women to study or to practice medicine in the Austro-Hungarian Empire hiring a female physician to serve in occupied Bosnia-Herzegovina was not lost on contemporaries. A Czech women's journal reporting on the event, however, rejoiced especially at the fact that the physician was a Czech and emphasized her role as a guardian of the health and "moral sensitivity" of Slavic Muslim women. Anna Bayerová had studied medicine in Switzerland. In 1891 she applied for the position of state physician in Bosnia, hoping that this would eventually enable her to practice medicine in Bohemia. On the way to her new post, she stopped in Vienna to meet Benjamin

1 “První státní lékařka v Evropě," Ženské listy, February 1892, 35.

(C) JITKA MALEČKOVÁ AND CHARLES UNIVERSITY, FACULTY OF ARTS, 2021 | 
Kállay, the joint minister of finance of the Austro-Hungarian Empire, who since 1882 was responsible for the administration of Bosnia-Herzegovina. His encouragement raised Bayerovás hopes for the future: she believed that the government was going to allow women to practice medicine also in Austria. ${ }^{2}$

Female physicians became part of Austro-Hungarian attempts to find the best way to govern the former Ottoman provinces of Bosnia and Herzegovina, which Austria-Hungary had occupied in 1878. The occupation presented the Austro-Hungarian administration with the challenge of ruling in a different type of setting where the population included a large proportion of Muslims: ${ }^{3}$ according to the 1879 census, 43 percent of the inhabitants of Bosnia-Herzegovina were Orthodox/Serbs, 18 percent were Catholic/Croats, and nearly 39 percent Muslims. ${ }^{4}$ The complex ethnic make-up of Bosnia-Herzegovina made it the target of territorial claims from Serbia and Montenegro, as well as the Ottoman Empire and Austria-Hungary. To prevent identification and potential alliances with the ethnically close Slavic states, Kállay supported the creation of a "Bosnian nationality." In his search for allies, apart from the small Catholic minority, which was supposed to be naturally aligned with the Catholic Habsburg Empire, Kállay looked for allies among the Muslim elites who had been in power in the Ottoman provinces before the occupation. ${ }^{6}$ His administration supported the Bosnian-Muslim press and schools for Muslim children, and by employing female physicians it sought to reach out particularly to Muslim women and present itself as a bearer of progress. ${ }^{7}$

The nature of Autria-Hungary's relationship to the occupied territories has been a matter of controversy. ${ }^{8}$ Although scholars focus primarily on the

2 Unable to get her diploma recognized in Austria-Hungary, Bayerová went to practice in Bern. See Ctibor Nečas, Mezi muslimkami: Působení úředních lékařek v Bosně a Hercegovině v letech 1892-1918 (Brno: Masarykova univerzita, 1992), 27-30.

3 After acquiring control of areas with a Muslim population, the Habsburgs tried to present themselves as the governors of Oriental peoples and territories: already at the 1882 exposition celebrating the anniversary of Austrian rule in Trieste the government presented a "Turkish style" Bosnian pavilion. See Baskar, "Oriental Travels," 226-27.

4 Srećko M. Džaja, Bosnien-Herzegowina in der österreichisch-ungarischen Epoche (1878-1918): Die Intelligentsia zwischen Tradition und Ideologie (Munich: R. Oldenbourg Verlag, 1994), 39.

5 Ladislav Hladký, Bosna a Hercegovina: Historie nešt'astné země (Brno: Doplněk, 1996), 47-49.

6 According to Daneš, the new government tried to gain the support of the "Mohammedan nobility" by giving them access to modern culture, but most Mohammedans felt no affection for the new administration. See Jiří V. Daneš, Bosna a Hercegovina (Prague: Český čtenář, 1909), 92.

7 Nečas, Mezi muslimkami, 122. On the Habsburg cultural mission see Robin Okey, Taming Balkan Nationalism: The Habsburg "Civilizing Mission" in Bosnia, 1878-1914 (Oxford: Oxford University Press, 2007).

8 On the history of Bosnia-Herzegovina under Austro-Hungarian occupation see Clemens Ruthner et al., eds., WechselWirkungen: Austria-Hungary, Bosnia-Herzegovina, and the 
attitudes of the Austro-Hungarian administration's representatives, intellectuals, and writers, and the institutions of governing and Austro-Hungarian enterprises have not yet been sufficiently analyzed, existing literature as well as early 2oth-century sources suggest that there are grounds to raise the question of colonial dominance over Bosnia-Herzegovina. ${ }^{9}$ The Austro-Hungarian government looked for inspiration in the policy of more established colonial empires, particularly British rule over the Muslims in India, ${ }^{10}$ and at least some contemporaries viewed the Austro-Hungarian regime as a colonial power, as the words of Jiř́ V. Daneš, a Czech professor of geography, from 1909 suggest: "Bosnia and Herzegovina have become a colony, the management of which has been modelled on the example of European settlements in other continents. The domestic population was meant to remain passive targets of care coming from the higher-ups, grateful for everything that the government introduced."1 While Czech historians tend not to view Bosnia-Herzegovina as a former colony, Pieter Judson calls it "the empire's lone colony - or protectorate,"12 and others speak of a quasi-colonial relationship ${ }^{13}$ or consider the occupation in 1878 to be "pure colonialist expansionism"; the justification for it, according to Stijn Vervaet, may have come from the perceived backwardness and Oriental

Western Balkans, 1878-1918 (New York: Peter Lang, 2008). On Austro-Hungarian colonial ambitions and a postcolonial perspective on Austrian literature see Alexander Honold, "Kakanien kolonial: Auf der Suche nach Welt-Österreich," in Kakanien Revisited: Das Eigene und das Fremde (in) der östereichisch-ungarischen Monarchie, ed. Wolfgang MüllerFunk, Peter Plener, and Clemens Ruthner (Tübingen: A. Francke Verlag, 2002), 104-20; Clemens Ruthner, “'K.(u.)k. postcolonial?' Für eine neue Lesart der österreichischen (und benachbarter) Literatur/en," in Müller-Funk, Plener, and Ruthner, Kakanien Revisited, 93-103.

9 Daneš (Bosna a Hercegovina, 138-39) stated that the Austro-Hungarian administration supported the settlement of "German peasants"; foreign "colonists" (including German, Czech, Italian, Polish, Magyar, and Ukrainian families) received 21,892 hectars of land, but this practice was interrupted after 1905 due to protests from the local population. Also Benno Gammerl in his comparative study of British and Habsburg imperial policy regarding ethnic diversity calls Bosnia-Herzegovina the only colonial possession of the Habsburg Empire. See Benno Gammerl, Staatsbürger, Untertanen und Andere: Der Umgang mit ethnischer Heterogenität im Britischen Weltreich und im Habsburgerreich 1867-1918 (Göttingen: Vandenhoeck and Ruprecht, 2010), 151 and 214. Gammerl (Staatsbürger, Untertanen und Andere, 214, note 220) quotes Milojković-Djurić, according to whom Bosnia was by contemporaries called "our European India."

11 Daneš, Bosna a Hercegovina, [3].

12 Judson, The Habsburg Empire, 378.

13 Raymond Detrez, "Colonialism in the Balkans: Historic Realities and Contemporary Perceptions," Kakanien Revisited (2002): 3, accessed December 20, 2017, http://www .kakanien-revisited.at/beitr/theorie/RDetrezı.pdf. 
character of Bosnia-Herzegovina. ${ }^{14}$ And the Austro-Hungarian project is also viewed as imperialist by Robin Okey, who has devoted extensive attention to Austria-Hungary's "civilizing mission," whereby it sought to compete with the civilizing missions of the Southern Slavs and to protect the empire from them. ${ }^{15}$ Some scholars argue that the occupation gave rise to a specific type of Orientalism that originated in the Austro-Hungarian Empire. ${ }^{16}$ Andre Gingrich coined the term "frontier Orientalism" to describe the attitude that constructs a contested border, where the eternal "we," the Austrians, are contrasted with the Oriental "Turk," later transformed into a Bosnian colonial subject: in the Austrian imaginary, the Turks were a metaphor for "the Bad Muslims," the former dangerous invaders and later defeated and humiliated opponents. Bosnian Muslims, in contrast, had by the end of the colonial period become "the Good Muslims," loyal, armed allies, who fought for Austria-Hungary against the Serbs. ${ }^{17}$ Johann Heiss and Johannes Feichtinger suggest that after the occupation, a dichotomy started to develop between "good Orientals" - the Christian and Muslim Slavs of Bosnia-Herzegovina living in the Orient "close to home" and "bad Orientals," i.e. the Muslim Turks, whether they lived in the occupied territories or in the Ottoman Empire, that is, in the "distant Orient."18 The Orient "close to home" provided an opportunity for "actual or quasi-colonial

14 Stijn Vervaet, "Cultural Politics, Nation Building and Literary Imagery: Towards a PostColonial Reading of the Literature(s) of Bosnia-Herzegovina 1878-1918," Kakanien Revisited (2009): 10-11, accessed December 20, 2017, http://www.kakanien-revisited.at/beitr/ fallstudie/SVervaet2.pdf. Also Austro-Hungarian sources show that Bosnia and Herzegovina were perceived as backward countries. Thus, education was considered "absolutely primitive" before the occupation and so were houses in Bosnia and other aspects of the local population's lives and activities, primitive even by the standards of "today," i.e. at the turn of the century. See Die österreichisch-ungarische Monarchie in Wort und Bild, vol. 22, Bosnien und Hercegovina (Vienna: Kaiserlich-königliche Hof- und Staatsdruckerei, 1901), esp. 330 and 345 . I am grateful to Pieter Judson for bringing this source to my attention. Okey, Taming Balkan Nationalism, viI.

16 Vesna Goldsworthy, Maria Todorova, Bakić-Hayden (and in a way also Larry Wolff writing on Eastern Europe) and others in the 199os were already persuasively demonstrating that post-Enlightenment Eurocentrism and 19th-century imperial projects had a major impact on Europe itself. See Goldsworthy, Inventing Ruritania; Maria Todorova, Imagining the Balkans (Oxford: Oxford University Press, 1997); Milica Bakić-Hayden, "Nesting Orientalisms: The Case of Former Yugoslavia," Slavic Review 54, no. 4 (1995): 917-31; Larry Wolff, Inventing Eastern Europe: The Map of Civilization on the Mind of the Enlightenment (Stanford: Stanford University Press, 1994).

17 Gingrich, "Frontier Myths of Orientalism," 110 and 107.

18 Johann Heiss and Johannes Feichtinger, "Distant Neighbors: Uses of Orientalism in the Late Nineteenth-Century Austro-Hungarian Empire," in Hodkinson et al., Deploying Orientalism, $148-65$. 
enterprises and made possible the notion of civilizing missions by the empire."19

In the late 19th century, the Czech lands ranked among the economically most developed regions of the Habsburg Empire. Czech-speaking entrepreneurs and professionals took an active part in the Austro-Hungarian expansion. They founded factories and construction firms in Bosnia-Herzegovina, Czech capital helped to finance local businesses, and Czech financial institutions established branch offices in Sarajevo. ${ }^{20}$ The Czechs, speakers of a Slavic language that the local population could understand, served as clerks in the Austro-Hungarian administration in Bosnia-Herzegovina. Bosnia-Herzegovina provided many Czech teachers, doctors, architects, officers, and skilled and unskilled workers with work. ${ }^{21}$ State-employed physicians Anna Bayerová and her colleague Bohuslava Kecková, who worked in Mostar from 1893 to 1911, were part of a stream of Czechs who temporarily or permanently settled in Bosnia-Herzegovina. Despite Kállay's encouragement, Bayerová had to face numerous obstacles in Tuzla, ranging from difficult dealings with her superiors and excessive administrative duties to problems with her salary and the hardships involved in traveling around the province in freezing weather day and night. As she was unable to find an apartment, she rented what she described as a noisy and dirty place above the worst Turkish café in town. ${ }^{22}$ She was eventually able to get a transfer to Sarajevo, where she was in close contact with Paulina Irby, the famous British author of travel books on Southeastern Europe and the founder of a school for Serbian girls in Sarajevo. ${ }^{23}$ Even in Sarajevo, Bayerová complained, her administrative duties prevented her from taking care of her patients as she had to sit in an office full of men, and no Muslim woman would be allowed to enter such a room. Having drafted a critical report

19 Heiss and Feichtinger, "Distant Neighbors," 150. Scholars dealing with Bosnia-Herzegovina focus especially on literary sources, however, and thus they do not answer the question as to whether Austria-Hungary's activities in Bosnia-Herzegovina differed from their enterprises in other parts of the empire and can be rightly labelled "colonial."

20 See Ctibor Nečas, Na prahu české kapitálové expanse: Rozpínavost českého bankovního kapitálu ve střední, jihovýchodní a východní Evropěv období rakousko-uherského imperialis$m u$ (Brno: Univerzita J.E. Purkyně, 1987), esp. 27-31 and 63-65.

21 Ladislav Hladký, "Podíl Čechů na kulturním a společenském povznesení Bosny a Hercegoviny v letech 1878-1918," Slavia, no. 1-3 (2008): 265-75. Czechs made up about 13 percent of the Austro-Hungarians in Bosnia-Herzegovina; see Zdeněk Uherek et al., Češiv Bosněa Hercegovině: Úvod do problematiky s výběrovou bibliografí (Prague: Etnologický ústav Akademie věd České republiky, 2000), 8-9.

22 Anna Honzáková, Dr. Med. Anna Bayerová, 1853-1924: První česká lékařka ve Šrýcarech (Prague: Nákladem Ženské národní rady, 1937), 24-27; Nečas, Mezi muslimkami, 30-38.

23 Nečas, Mezi muslimkami, 32 and 39; on Irby see Goldsworthy, "The Balkans," 29-30. 
on the situation, she resigned from her job, just one year after arriving in Bosnia. Nevertheless, her pioneering role as a female physician and the selfless assistance she gave to poor Muslim and other women in Bosnia have been acknowledged by Czech and international historians alike. ${ }^{24}$

Bayerová's story is one small but significant piece in the larger picture and narrative of Czech involvement in the occupied provinces, a story of "Czech help" in the cultural and economic advancement of Bosnia-Herzegovina, a story that was constructed in the 19th century and is still accepted by historians today. In this narrative, the beginnings of the Czech presence in BosniaHerzegovina were far from auspicious. The Czechs participated in the seizure of Bosnia-Herzegovina and the suppression of opposition from the local, mainly Muslim, population. The inhabitants of the occupied provinces first thought of the Czechs as Švábe (Germans from the Austro-Hungarian Empire) and as kuferaši (from kufer, i.e. suitcase), people arriving in Bosnia-Herzegovina with a suitcase and a plan to get rich, much like the "carpet-baggers" after the American Civil War. ${ }^{25}$ Gradually, however, the local people are claimed to have understood that the Czechs were either trying to build a professional career there or were motivated by a sincere (Pan-)Slavic sentiment. In the late 19th and early zoth centuries, so the story continues, the Czechs contributed significantly to the development of the Bosnian economy, education, and culture and distinguished themselves as architects, musicians, and scholars, and as the founders of local museums. They also worked as successful engineers, lawyers, geodesists, pharmacists, and doctors, not to mention the many who were employed as skilled and unskilled workers and craftsmen. ${ }^{26}$ The Czechs allegedly even helped to represent Bosnia to the world: Alfons Mucha was commissioned by the French organizer of the Exposition Universelle in Paris in 1900 to decorate the Bosnian pavilion. ${ }^{27}$ In short, the Czechs believe themselves to have helped to create modern Bosnia.

24 Nečas, Mezi muslimkami, 49-50; Brigitte Fuchs, "Orientalizing Disease: Austro-Hungarian Policies of 'Race,' Gender, and Hygiene in Bosnia and Herzegovina, 1874-1914," in Health, Hygiene, and Eugenics in Southeastern Europe to 1945, ed. Christian Promitzer, Sevasti Trubeta, and Marius Turda (Budapest: Central European University Press, 2011), 83; Brigitte Fuchs, "Austria-Hungary's Civilizing Mission in Bosnia and Its Positive Effects on Domestic Feminists' Demands 1890-1918" (paper presented at the conference "Gender and Empire: Exploring Comparative Perspectives and Intersectional Approaches," Global South Studies Center, Universität zu Köln, September, 2015).

25 Hladký, "Podíl Čechů," 267.

26 Ibid., 268-70.

27 Milan Hlavačka, "L'Exposition Universelle - Světová výstava 1900 v Pařiži: Fenomén světových výstav v druhé polovině 19. století," in Alfons Mucha - Pař́ž 19oo: Pavilon Bosny a Hercegoviny na světové výstavě, ed. Milan Hlavačka, Jana Orlíková, and Petr Štembera 
There is no doubt that many of these activities benefited the people of Bosnia-Herzegovina and, in some cases, their main purpose might have been to help the Czechs' "Slavic brothers." However, the narrative of selfless help ignores an important aspect of Czech involvement in the region: for those who worked in or for Bosnia-Herzegovina, this was also an opportunity to get a job and earn money. The first female doctors, Bayerová and Kecková, were no exceptions. ${ }^{28}$ It was difficult to get a job as a physician abroad and nearly impossible in the Austro-Hungarian Empire; after returning from Bosnia, Bayerová indeed struggled to find a job in Prague. Thus, "official service in the occupied territories was for them one of the few solutions."29 Regardless of the difficulties and sacrifices connected with the task of being the first female physicians in Bosnia, ${ }^{30}$ their work in Bosnia-Herzegovina should also be seen in this pragmatic light. As should the activities that other Czechs pursued there.

This chapter analyzes Czechs' attitudes toward the former Ottoman provinces Bosnia and Herzegovina and their Muslim population. The relationship Czechs had with this group was made more complex by the fact that the "nearby Muslims" of Bosnia-Herzegovina were Slavs like the Czechs themselves. Given the prevailingly secular character of Czech nationalism, the chapter asks how much it mattered that these Slavs were at the same time Muslims whom the Czechs called "Turks." While the previous chapter, examining journeys by Czechs into the Ottoman realm, addressed Oriental travels in a non-colonial setting, here the focus shifts to Czech colonial ambitions or "colonial complicity." According to some scholars, in societies outside Western centers "colonial complicity" characterized their participation in hegemonic discourses and practices of dominance as a way of approximating a model of relating to nonEuropean societies introduced by Western powers. ${ }^{31}$ The Czech case was an example of "colonialism without colonies," a concept that refers to "the presence and perseverance of colonial structures and power relations in countries that, according to the hegemonic (self-) representation, have not been part of the colonial projects." ${ }^{32}$ The chapter first describes Czechs' views on Slavic

(Prague: Mucha Trust, 2002), 29-30. Mucha was, of course, commissioned by the imperial authorities and thus, regardless of his national or Pan-Slavic feeling, he was acting as an agent of the Habsburg Empire.

Kecková wrote that the salary she received from the government was 1600 florin (the currency in Austria-Hungary until 1892). Bohuslava Kecková, "Z lékařské činnosti MUDr. Bohuslavy Keckové," Lada, no. 2 (1895): 14.

29 Nečas, Mezi muslimkami, 124.

30 Ibid., 32-47.

31 See Lüthi, Falk, and Purtschert, "Colonialism without Colonies," 4.

32 Ibid., 5 . 
Muslims, arguing that they were essentially ambivalent. It then presents Bosnia-Herzegovina as the "near Orient," which was a destination for Czech tourists. The next parts of the chapter describe the Czechs' attitudes toward the Austro-Hungarian occupation of Bosnia-Herzegovina and set them in the context of Czech colonial ambitions.

\section{$1 \quad$ What's in a Name?}

The Czechs had no single term with which to refer to the Slavic Muslims of Bosnia-Herzegovina. They often just called them "Turks," though they occasionally distinguished "local Turks," i.e. the Slavic converts to Islam, from the "true Turks" in Asia, sometimes called Ottomans or Ottoman Turks. Also quite common was the more pejorative Turčini, used to denote both Slavic Muslims and Ottoman Turks, ${ }^{33}$ and the most unambiguously negative Poturčenci (i.e. the Turkified). ${ }^{34}$ Mohamedáni (Mohammedans), a term that was originally also used in official documents of the Austro-Hungarian administration, ${ }^{35}$ was more popular than "Muslims" (moslimové, Moslemini ${ }^{36}$ ), and appeared alongside "Mohammedan Slavs/Serbs" and, more rarely, "Bosnians." The various terms were used inconsistently and often interchangeably within a single piece of writing or even on a single page, as illustrated by the words of the writer and teacher Antonín Zavadil: "Bosnian Mohammedans call themselves Turčíns, they have not renounced their Slavic origin and have not forgotten their Mohammedan language, but they have always been fanatic in their opposition to their Slavic compatriots who were of a different religion, as the proverb says: a Turkified person is worse than a Turk." ${ }^{37}$ This terminological variation was, this chapter argues, indicative of Czechs' ambivalent feelings about Slavic Muslims.

In postcolonial studies, ambivalence denotes "the complex mix of attraction and repulsion that characterizes the relationship between colonizer and

33 Krásnohorská, Kslovanskému jihu, 16, 79, 135-37, and 195; Mayerhofer, Ilustrovaná kronika, 110; Knotek, Balkán, 44; Zavadil, Obrázky z Bosny, 28 and 32.

34 Třeštík, Ku břehům Adrie, 61; Josef J. Toužimský, Bosna a Hercegovina v minulosti a př́tomnosti (Prague: Spolek pro vydávání laciných knih českých, 1882), 93 and 124; Zavadil, Obrázky z Bosny, 28.

35 Hladký, Bosna a Hercegovina, $5^{0 .}$

36 Mayerhofer, Ilustrovaná kronika, 110; Svátek, Vzemi půlměsíce, 41; Klaus, Do řǐše půlměsíce, 224-25.

37 Zavadil, Obrázky z Bosny, 28. 
colonized." ${ }^{38}$ The concept applies mostly to the colonized population's relationship to the colonizers, oscillating between rejection of and complicity with colonialism or incorporating both. However, it also refers to colonial discourse and its patronizing attitude toward the colonized; it describes an approach that (cl)aims to elevate the "indigenous people" while simultaneously trying to capitalize on them. This understanding of ambivalence can also be applied to the asymmetry of power created by the Austro-Hungarian occupation of Bosnia-Herzegovina.

The occupation markedly increased the Czech interest in and need for information about Bosnia-Herzegovina. The two major Czech 19th-century encyclopedias illustrate how much this interest grew in the second half of the 19th century: in 186o, Rieger's Slovník naučný (The Encyclopedia) devoted fewer than six pages to "Bosnia,"39 while the entry on Bosnia (with Herzegovina) in Ottưv slovník naučný (Otto's Encyclopedia) in 1891, written by six authors, was 16 pages long. ${ }^{40}$ Both encyclopedias stated that the local "Mohammedans" were descendants of the old Bosnian nobility, who converted to Islam in order to keep their estates, and some of them were urban craftsmen and traders; they called themselves Turks (Turčini), but had not forgotten their origins and national language; in fact, both entries on Bosnia alleged, the begs had preserved the purest Serbian language, but soiled it by mixing in Turkish words. Both encyclopedias described them as fatalists and often religious fanatics, interested only in ruling others. ${ }^{41}$ According to Ottuov slovnik naučný, the Bosnian Mohammedans' Slavic origin was evident in the fact that they had not embraced polygamy (unlike fatalism and fanaticism). Until the occupation, they had been the worst enemies of their Christian brothers, which was reflected in surviving local idioms: it is a sin to kill a dog or an ox, but to kill a Christian is to be commended; and a Turk can do what he likes with the Orthodox, as long as he washes his hands afterwards..$^{42}$

Czechs held the view that the Bosnian church had adopted the theology of the persecuted Bogomils, a dualistic religious sect founded in Bulgaria in the 1oth century. ${ }^{43}$ This theory helped explain how it was that some Slavs had

38 Bill Ashcroft, Gareth Griffiths, and Helen Tiffin, Post-Colonial Studies: The Key Concepts (London: Routledge, 2007), 10-11.

39 Rieger, Slovník naučný (Prague: Kober and Markgraf, 1860), 1:822-27.

40 Ottův slovník naučný (Prague: J. Otto, 1891), 4:428-44.

41 Rieger, Slovník naučný, 1:824; Ottův slovník, 4:432.

42 Ottův slovník, 4:432-33. These idioms, together with other information, were later repeated in travelogues. See, e.g., Zavadil, Obrázky z Bosny, 28.

43 See John V.A. Fine, "The Medieval and Ottoman Roots of Modern Bosnian Society," in The Muslims of Bosnia-Herzegovina: Their Historic Development from the Middle Ages to the 
become Muslims: the Slavic Muslims were considered descendants of Bosnia's former nobility, most of whom were Bogomils, who, in order to preserve their rights and property after the Ottoman conquest, had adopted the faith of their Muslim conquerors en masse. Local rulers' persecution of the Bogomils combined with European states' attitude toward them during the Ottoman conquest made this population more willing to convert to Islam under "Turkish" rule, after which the local Muslims became the ruling class, though they did not hesitate to fight with the Ottoman Turks for their privileges. ${ }^{44}$

The uprisings in Bosnia and Herzegovina in 1875, as we saw in the first chapter, strengthened Czech animosity toward the Turks, who seemed villainous in the eyes of some - Holeček, for instance, wrote in 1876 how Montenegrins grew cautious whenever they saw someone approaching who might, as he put it, be "a bad person or even a Turk." 45 This animosity extended also to "local Muslims" in Bosnia and was expressed in the pejorative label "Turkified" (Poturčenci). There is an old Czech saying that "a Turkified person is worse than a Turk"; it was also cited by Zavadil and is still used today to describe how new converts can be even more zealous than old believers. Christian apostates who had betrayed their faith and accepted the religion of the enemy were considered to be more violent and fanatic defenders of Islam than the Turks themselves. In 1882 the journalist Josef Jakub Toužimský wrote that Bosnia-Herzegovina had suffered more than any other country under Turkish rule; the Christians might have been able to endure the Turks, but they could not do so and simultaneously resist the local nobility who had accepted Islam. "The Bosnian and Herzegovinian Turkified have become not only zealous adherents of Islam but also the jealous defenders of their privileges, and opponents of anything new."46

Reports from Czechs who had participated in the conquest of BosniaHerzegovina and the suppression of the subsequent local Muslim uprisings breathed new life into the stereotype of the "terrible Turk," and now it was applied also to Slavic Muslims. One such account, while it was far from supportive of the incursion into Bosnia-Herzegovina and criticized Austrian military officers, portrayed the local "Turks" as barbarians and beasts who tortured

Dissolution of Yugoslavia, ed. Mark Pinson (Cambridge, MA: Harvard University Press, 1996), 8.

Dvacet let práce kulturní: Cesta Bosnou a Hercegovinou, již vykonali J.U.Dr. Emanuel Dyk, Max Hájek, František König, říššti i zemští poslanci (Plzeň: Knihtiskárna J. Císaře, 1899), 14-15; Ludvík Kuba, Čtení o Bosně a Hercegovině: Cesty a studie z roků 1893-1896 (Prague: Družstevní práce, 1937), 47; Třeštík, Ku břehům Adrie, 21 and 61-63; Jan M. Černý, Hercegovina: Země a lid; Dle zápisků vlastenců a zkušeností cizinců (Prague: J. Otto, 1876), 9-10. Holeček, Černá Hora, 27.

46 Toužimský, Bosna a Hercegovina, 93-94. 
their captives, forced them to kiss their feet, and cut the heads off dead enemies. ${ }^{47}$ Another participant in the fighting repeatedly compared the Muslims to cannibals: "...we stood fully armed against the abominably cannibalistic enemy, and I am not exaggerating, the Zulus, Bagirmis, Nyam Nyams, Bechuans, Hottentots and similar South African tribes behaved with more chivalry toward European travelers than the Bosnian Turks did toward us."48

Although a shift in Czechs' views of Muslims can be identified between the late 1870 s and the 19oos, their views did not develop linearly, but were marked by both continuity and constant variation. Thus, not all the participants in the fights in Bosnia-Herzegovina in the late 1870 s and early 1880 s saw their adversaries as cannibals and beasts; some painted a complex picture of the Muslims they had fought. In his memoirs Ignát Hořica described the violence on the Austrian and "Turkish" sides as comparable. The Muslims did sometimes cut off an enemy's head, but he portrayed them as brave defenders of their country against invaders. One chapter in the memoir that recalls a "Turkish fanatic" executed for murder points out that the murder was a reaction to similar acts committed by the Austrian army ${ }^{49}$ Hořica believed the war to have been absurd: "How many men of the beautiful and healthy Slavic tribe were annihilated so quickly! It was also a war of brothers against brothers, and [look] how it was waged!"50

The distinction between the Slavic Muslims of Bosnia-Herzegovina and the Ottoman Turks was often blurred. But the association was sometimes made on the basis of some kind of Ottoman or "Turkish" heritage. A renowned historian, Čeněk Zíbrt, argued in 1909 that the current problems in Bosnia-Herzegovina should be dealt with in the same way (by arms) that Czech treatises had proposed tackling the Turkish threat - but that was back in the early modern period! ${ }^{51}$ The two groups continued to be conflated after the annexation. The writer and journalist Josef Jan Svátek (whom we met in the previous chapter) explained that the annexation generated a need for a better understanding of Turkey, because "our wish is that after the annexation of Slavic Bosnia and Herzegovina not only will those countries in which the Turkish influence is still excessively felt take to us kindly, but also the rest of the Turkish Empire will live

47 Povstání v Bosně: Pravdivé př́hody rakouského vojáka v Bosně a Hercegovině (Prague: A. Reinward, 1883), 74-80.

48 Edmund Chaura, Obrázky z okupace bosenské (Prague: Př́tel domoviny, n.d., ca. 1893), $37-38$.

49 Hořica, Smutné i veselé z Bosny a Hercegoviny, 47.

5o Ibid., 43 .

51 Čeněk Zíbrt, "Balkánská otázka a Bosna i Hercegovina ve světle staročeských knih o Turecku," pt. 4, Zlatá Praha, December 11, 1909, 140. 
in peace and friendship with us."52 Repeating the saying about Bosnian Muslims looking more favorably on dogs than on Christians, Antonín Zavadil argued in 1911 that this explained the number of dogs that could be seen "in Constantinople." 53 And there are more examples revealing how much the Muslims of Bosnia-Herzegovina and the Ottoman Turks were closely connected, or even interchangeable, in the minds of Czechs.

Most Czech writers at the same time paradoxically emphasized that the Muslims of Bosnia-Herzegovina, despite their religion, were Slavs and were thus their (Slavic) brothers. It is interesting to ask, however, whose brothers the Czechs thought the Muslims were. Edin Hajdarpasic has suggested the concept of (br)other to describe the attitude of Christian Serbs and Croats to their Muslim compatriots in Bosnia: "The co-national, in this understanding, is the national (br)other: signifying at the same time the potential of being both 'brother' and 'Other', containing the fantasy of both complete assimilation and ominous, insurmountable difference - and thus making visible a range of passages between seeming opposites." ${ }^{4}$ Hajdarpasic has highlighted the efforts that were made to "nationalize Bosnian Muslims" and the local Muslim population's varying responses to the nationalist rhetoric, which complicated the nationalists' plans and the neat categorization that was imposed by the Austro-Hungarian administration - and also employed by Czech observers.

According to the Czechs, the Muslims shared with the Christians of BosniaHerzegovina the same habits and customs, interests, and legal consciousness, which revealed their common Slavic roots. ${ }^{55}$ Czechs argued that the Muslims of Bosnia might have called themselves Turks, but many did not speak Turkish, and they pointed out that some "true Turks" who had settled in Bosnia and Herzegovina had in fact adopted the local language. They observed that the Muslims were speaking Serbo-Croatian like everyone else in their home country and felt a real patriotic love for the language. ${ }^{56}$ Czech writers were astonished by the Muslims' deep, even "fanatic" devotion to Islam, but claimed that many of these Muslims knew little about Muhammad's teachings. ${ }^{57}$ What most obviously and significantly showed the Muslims to be Slavs in the eyes of Czech observers was their family habits: Muslims shared with their Christian

\footnotetext{
$5^{2}$ Svátek, Vzemi půlměsíce, 1, 24-25, and 54-55.

53 Zavadil, Obrázky z Bosny, 28.

54 Edin Hajdarpasic, Whose Bosnia? Nationalism and Political Imagination in the Balkans, 1840-1914 (Ithaca, NY: Cornell University Press, 2015), 16.

55 Dvacet let práce kulturní, 17.

56 Třeštík, Ku břehům Adrie, 21-22; Toužimský, Bosna a Hercegovina, 119; Dvacet let práce kulturní, 14-15; Daneš, Bosna a Hercegovina, 92; Kuba, Čtení o Bosně, 60.

57 Třeštík, Ku břehům Adrie, 21-22.
} 
compatriots a patriarchal mentality, they were monogamous and did not exercise the right of the Hanefite rite to four wives, they rarely divorced and their family life was orderly, with an admirable companionship and mutual respect shown among family members. ${ }^{58}$ The family life of the Muslims was considered exemplary. Holeček wrote that society would not be lost as long as the strong basis of the pure Mohammedan family life remained unshaken. ${ }^{59} \mathrm{He}$ went so far as to claim that, "[i]n truth, one does not find among the Western Christians either as much conjugal love or as much family love as among the Mohammedans." 60

Czechs for the most part did not explicitly call Slavic Muslims the "Czechs' brothers," they were considered rather the brothers of the Serbs and Croats, with whom it was felt they should eventually unite. That the Serbs and Croats were the Czechs' brothers implied that the Slavic Muslims were too, but this was not a kinship emphasized by most Czechs, who focused instead on how desirable it would be for unity and brotherhood to form among the religiously divided Slavs of Bosnia-Herzegovina. The article celebrating Bayerovás appointment quoted at the beginning of this chapter was exceptional in that it spoke about "her Slavic sisters, the Mohammedan Serbs in Bosnia." ${ }^{61}$ Czech women did not generally call Muslim women their "sisters" any more than they called Muslim men their brothers. For example, describing her travels through Bosnia-Herzegovina and Montenegro, Máša Absolonová wrote about "our Slavic brothers," the Serbs and Montenegrins, but she associated the Muslims (moslemini) with danger, noting that a military presence was necessary in the Muslim-inhabited area. ${ }^{62}$

Compared to their Christian compatriots, the Muslims were considered less refined and civilized. In an article about her impressions from Bosnia, published in 1893, Bayerová praised the Bosnian Muslims' ability to choose the most beautiful locations for their homes, but claimed that the people lacked order, an interest in useful gardening, and good taste. She had seen many tasteless reproductions of art works or pictures of Mekka, including a terrible fresco of the bridge in Mostar, and she found portraits only in the homes of the most "advanced" Mohammedans. She commented ironically on the Muslims' love for onion and garlic, which made them recognizable as soon as they entered a

\footnotetext{
$5^{8}$ Třeštík, Ku břehům Adrie, 22; Toužimský, Bosna a Hercegovina, 123-24.

59 Josef Holeček, Bosna a Hercegovina za okupace (Prague: Josef Holeček, 1901), 63.

6o Holeček, Bosna a Hercegovina, 46.

61 "První státní lékařka v Evropě," 35.

62 Absolonová, “Přes hranice Černé Hory," 305. Marie Absolonová (1888-?), née Marvánková, accompanied her husband, the famous archeologist and paleontologist Karel Absolon, on his travels to the Balkans in 1908 and 1912-1913 and took pictures documenting the trips.
} 
room, and on other habits that she felt showed their lack of civilized manners. ${ }^{63}$ Her words suggest that she viewed Islam not as causing Slavic Muslims' animosity or fanaticism, but rather as a cultural issue, and as responsible for their "backwardness." 64

Nonetheless, both Bayerová and her colleague Kecková clearly cared about their local patients, including the Muslim women. In a letter to a friend in 1892 Bayerová wrote how pleased she was with "her Mohammedan women"; it was only because of them that she had not given up her job. ${ }^{65}$ Kecková noted that 360 of her 710 patients in 1893 were Muslim women and she attributed her achievements to the support provided by the government, the Mostar newspapers, and the Catholic, Orthodox, and Muslim religious representatives who recommended her to local women. She added that even the doctors in Mostar accepted her without jealousy. Perhaps owing to the undeniable success of her mission, she showed more sympathy than contempt for the Muslims. She claimed she was happy in her job and "loved her uneducated but open and sincere patients," whom she was glad to advise and help also in matters of the household. ${ }^{66}$ She stood by her words: she remained in Mostar as a doctor almost until her death in 1911.

As the examples mentioned so far make clear, there was much that was paradoxical about the ways the Czechs viewed the Muslims. The Muslims could be both portrayed as the defenders of Christians and called "Turkified" fanatics. ${ }^{67}$ The "Turkified" were seen to have preserved many habits from the Christian past: they demonstrated sincere hospitality and faithfulness in friendship and they practiced pobratimství, the brotherhood of choice, which could be established even between a Christian and a Muslim, and which was considered more sacred than kinship. At the same time, the Muslims were described as belligerent, as fiercely vengeful, and as hating outsiders, though so, too, sometimes were the Christians of Bosnia-Herzegovina. ${ }^{68}$ Even "fanaticism" could be interpreted positively: "The Mohammedans are famous for their pure

63 Anna Bajerová, “Črty z Bosny: Feuilleton; Domy Mohamedánů," pt. 1, Pšovan, April 9, 1893, [1-2]. In the article, Bayerová's name is spelled Bajerová.

64 Bayerová's article is preceded, in an earlier issue of the journal, by a brief report about Bayerovás lecture for the local audience, in which she described the social and family life of Bosnian Muslim women, their mores, upbringing, and superstitiousness. "Různé zprávy," Pšovan, March 12, 1893.

65 Nečas, Mezi muslimkami, 35 .

66 Kecková, "Z lékařské činnosti," 14.

67 Třeštík described how during the uprising some Muslim Bosnians defended the representatives of the Austro-Hungarian administration against attacks from their Turkish coreligionists. See Třeštík, Ku břehům Adrie, 63 .

Toužimský, Bosna a Hercegovina, 123. 
and honest character," Daneš wrote in 1909, "their religious fanaticism gives them moral support against the corruption coming from cultured Europe..." ${ }^{\prime 6}$ The associating of Slavic Muslims with religious fanaticism, which was stereotypically attributed to Ottoman Turks, was both widespread and persistent, and even appeared in contexts that were otherwise not entirely negative. ${ }^{70}$ Holeček clearly distinguished "our local Mohammedans" from the Turks. ${ }^{71}$ His views of the Slavic Muslims were embodied by a figure named Omer - one of "our Mohammedans" and an example of an "honest Turk." He wrote that at first sight Omer looked fierce and indocile, but it was not difficult to discover that his coarse appearance hid a "good and healthy core"; 72 yet when Omer got angry, he was the image of a "true Turkish fanatic."73

The ambivalence in the Czechs' views is reflected in a novel titled Péri, about the 1875 insurgence in Bosnia and Herzegovina, written by Bohumil Havlasa (1852-1877), a prolific writer of adventure novels and a journalist who reported on the Balkan uprisings and even took part in the fighting. The book presents a strange mixture of Orientalist stereotypes about belligerent, lazy, and nosy Turks ${ }^{74}$ garbled Turkish words, which Havlasa calls Arabic, and confused ethnic designations: he refers to the Slavic Muslims alternatingly as Turčins or Turks and as Muslims or Mohammedans, while elsewhere he distinguishes the "pure-blooded Turks" or Ottomans from the "Mohammedan Southern Slavs."75 The novel portrays local Christians and Muslims as equally violent: a Muslim village is destroyed by the Christian insurgents while a Christian village is annihilated by the "Turks."76 The narrator, a Czech supporter of the insurgents, is captured by the "Turks" and kept prisoner in the house of a local notable named Ibrahim, whose nephew Ahmed, depicted as beautiful and proud, clearly holds the author's attention and affection. ${ }^{77}$ Ahmed tries to prove that even a Muslim "can behave in European ways," but, betrayed by the narrator, he

69 Daneš, Bosna a Hercegovina, 92.

70 Třeštík, Ku břehům Adrie, 21-22; Dvacet let práce kulturní, 15.

71 In the mid-1870s he viewed the Ottoman Turks as evil, but later he acknowledged that they also had some positive qualities (especially when compared to the Austrians). See Holeček, Černá Hora, 27, and Holeček, Bosna a Hercegovina, 43.

72 Holeček, Bosna a Hercegovina, 16.

73 Ibid., 44.

74 Bohumil Havlasa, Péri (Prague: F. Šimáček, 1901), 18 and 22. A strongly anti-Turkish novel on the Austrian occupation of Bosnia and Herzegovina was published in the late 1870 . See, Krvavá Bosna aneb: Ukrutnosti mohamedánů, páchané na křest'anech, s ilustrovanou přllohou; Rakouská okupace Bosny a Hercegoviny, 3 vols. (Prague: A. Hynek, n.d.).

75 Havlasa, Péri, 22.

76 Ibid., 96 and 90 .

77 Ibid., 31 . 
swears he will only seek revenge. ${ }^{78}$ Nevertheless, when the insurgents help the narrator and his friends fight the Muslims and kill or capture most of them, the narrator saves Ahmed's life. This act marks the culmination of the complicated relationship between a Christian Czech and a Muslim Bosnian, a relationship that expresses how the Czechs viewed Slavic Muslims - as furious Orientals and their Slavic (br)others at the same time.

For too long the Czechs had remained at home, the politician Václav Klofác complained in the early 2oth century. Arguing that traveling broadens the mind, leads to new experiences, and turns theorists into practitioners, he felt that the young generation in particular should "go cheerfully and bravely out into the world, around the entire world, but around the Slavic world first."79 The only thing that the Czechs had known about the Balkan Slavs fifty years earlier, the historian and archivist Jan Bedřich Novák added at roughly the same time, was that they made a living stealing sheep and goats and had big noses, which they enjoyed cutting off each other's faces. With the expansion of tourism and economic ties in the late 19th century, interest in and understanding for other Slavs had increased, which in his view was grounds for optimism. ${ }^{80}$

The "Slavic South" and, after the occupation, Bosnia-Herzegovina in particular did indeed become popular destinations for Czech travelers and tourists. One famous visitor to the region was the painter Alfons Mucha, who went on a study trip to Bosnia in 1899 after being commissioned to decorate the BosnianHerzegovinian Pavilion at the Paris World Exhibition of $1900 .{ }^{81}$ This journey gave rise to a major Pan-Slavic work of art, "with allegorical frescos depicting Ottoman oppression, Sarajevo and the wealth of Bosnia, as well as embroidery and sculpture." 82 Many travelers added trips to the former Ottoman provinces to their journeys through other South Slavic regions. Czech travels to the

\footnotetext{
$78 \quad$ Ibid., 145 .

79 Václav Klofáč, "Ven - do slovanských zemí," in Slovanský jih: Články posl. V. Klofáče, L. Brunčka, DraJ.B. Nováka a J.Jasýho (Prague: Hejda a Tuček, 1911), 1.

$80 \quad$ J.B. Novák, "Mezi Adrií a Drávou (několik fragmentů)," in Slovanský jih, 12-13.

81 Hlavačka, "L'Exposition Universelle," 29-31.

82 Jeremy Howard, Art Nouveau: International and National Styles in Europe (Manchester: Manchester University Press, 1996), 19.
} 
territory of Bosnia-Herzegovina can thus be viewed as "emotional visits"83 made by Slavic brothers that were motivated by and reinforced the Pan-Slavic aspect of national identity. This understanding of the Czechs' relationship to Bosnia-Herzegovina appears to be in direct contrast to what Mary Louise Pratt has called a "contact zone": "the space in which peoples geographically and historically separated come into contact with each other and establish ongoing relations, usually involving conditions of coercion, radical inequality, and intractable conflict." 84 This raises the question of the subtext of the trips Czechs made to Bosnia-Herzegovina: Did they feel they were traveling to a remote part of the Slavic world, in which they felt at home, or to a part of the imperial domain; did they travel like East Europeans, as though they were essentially visiting other members of their own family, ${ }^{85}$ or did they travel like West Europeans, venturing out to inspect their colonies? And how did their trips to Bosnia-Herzegovina compare to their journeys to the Ottoman Empire?

One striking difference between Czech travel to the Ottoman Empire and to Bosnia-Herzegovina is that the latter was a destination of organized group tourism. The Czech Tourists' Club (кс̌т), founded in 1888, arranged its first trip to Dalmatia, Montenegro, and Bosnia-Herzegovina in 1897. The trip lasted 18 days and its 71 participants, including 17 women, came from Prague and from about 20 other towns and cities in Bohemia and Moravia (only one participant was from Vienna). Their occupations - real estate holders, factory owners, and wholesale traders - suggest that they belonged to the upper and upper-middle classes, though they were joined by a few teachers and a "peasant" family. Accordingly, they traveled in the first class of the train and, reportedly, in luxurious cabins on the boat. The trip was considered so important that three participants published travelogues about it. ${ }^{86}$ One of these travelogues was written by Jan Buchar, ${ }^{87}$ a Kс̌т member from Prague. It emphasized Slavic

83 On emotional visits see Noah W. Sobe, "Slavic Emotion and Vernacular Cosmopolitanism: Yugoslav Travels to Czechoslovakia in the 1920s and 1930s," in Turizm: The Russian and East European Tourist under Capitalism and Socialism, ed. Anne E. Gorsuch and Diane P. Koenker (Ithaca, NY: Cornell University Press, 2006), 82-96.

84 Pratt, Imperial Eyes, 5. Pratt (Imperial Eyes, 7) writes that her concept "treats the relations among colonizers and colonized, or travelers and 'travelees,' not in terms of separateness or apartheid, but in terms of copresence, interaction, interlocking understandings and practices, often within radically asymmetrical relations of power."

85 Bracewell, "The Limits of Europe," 61-120.

86 Třeštík, Ku břehům Adrie; Ferdinand Velc, "Sarajevo," Časopis turistů, April 1, 1897, 93-103; Jan Buchar, První výlet Klubu českých turistů do Dalmacie, Černé Hory, Hercegoviny, Bosny a Záhřebu ve dnech od 13. do 30. dubna 1897 (Prague: J. Buchar, 1898).

87 Buchar, Prvni výlet, [1-2]. The book also lists the names and professions of the participants (První výlet, 94-96). 
solidarity and focused on the respect and love the local population showed Czech travelers rather than on places of touristic interest, and it treated BosniaHerzegovina in the same way as Montenegro or Dalmatia, while perhaps just devoting a little more attention to the Czechs who lived in Bosnia-Herzegovina.

Among the Czechs in Bosnia-Herzegovina Buchar mentioned Ferdinand Velc, a member of the КČт from Sarajevo, and Professor Jan Třeštík, both of whom wrote travelogues describing the tour. ${ }^{88}$ Treštík, in a speech he gave to his fellow travelers, which Buchar quoted, praised the progress achieved in the twenty years of Austro-Hungarian rule: he claimed Czechs were among the pioneering figures working on the cultural and economic advancement of Bosnia-Herzegovina and held important jobs in the political, judicial, financial, and technical administration of the country; their role was outstanding also in education; they distinguished themselves as teachers, physicians, and officials and together with tradesmen helped to spread the good name of the Czechs. ${ }^{89}$ In his own travelogue, which focused on the part of the trip from Sarajevo to Dubrovnik, Třeštík stressed how much the trip was a boost to "Slavic solidarity"90 and appraised Czech enterprises in the region, noting in particular a trades school in Sarajevo, whose director and entire teaching staff, apart from the local catechist, were Czechs. ${ }^{91}$

In 1911 a similar tour of the South Slavic countries, lasting 26 days and including Bosnia-Herzegovina, was organized for a very different social group by the Czech Teachers' Union. One of its participants, Adolf Vojtěch Obst, described it in writing. ${ }^{92}$ This time, half of the 47 participants were women and, as well as teachers, a few (male) school directors and their family members took part in the trip. The travelogue resembled the previous accounts: it pointed out how the teachers were greeted with love and hospitality everywhere they went and was accompanied by photos of the towns and villages visited, taken by one of the participants. The travel book also contained a section devoted to local education and schools in each country, including curricula and specific educational features that reflected the religious differences of the pupils. Obst claimed that the government supported education in BosniaHerzegovina, which brought hope for the future and for the country's Muslims, alternatingly called Turčins, Turks, and Mohammedans. ${ }^{93}$ The more "learned"

\footnotetext{
88 Ibid., $63-64$.

89 Ibid., 64.

9o Třeštík, Ku břehům Adrie, 3-4.

91 Ibid., 8.

92 A.V. Obst, II. studijní výprava českého učitelstva v roce 19n: Př́moř́-Dalmacie-Černá HoraBosna a Hercegovina (Prague: Nákladem Fondů výprav učitelských, 1912).

93 All three terms can sometimes be found on the same page: Obst, II. studijní výprava, 61.
} 
character of this trip was reflected in the fact that the teachers had bought 46 publications about the countries they were going to travel through and used them to prepare for the journey. Especially welcome were the guidebooks written in Czech and published by the "Máj" Association and the KČT, which, Obst noted with satisfaction, could be used instead of foreign publications. But for more detailed information it was still necessary to read the more abundant German guidebooks. ${ }^{94}$

People who visited Bosnia-Herzegovina at the turn of the century were luckier than the prevailingly individual travelers to the Middle East, who could not use Czech-language guidebooks. ${ }^{95}$ Velc's guide, published in 1907 by the KČT, claimed to be the first travel guide to Bosnia-Herzegovina published in Czech. It included a brief history of the country, a more detailed outline of possible travel routes to Bosnia, and descriptions of suggested excursions within the country, and it mentioned the many Czech stores, businesses, and pubs that could be found in different towns. It was accompanied by a map of BosniaHerzegovina and photos, most of them views of cities, architecture, and nature, but also of local people in their "Oriental" costumes. The author, a Czech living in Sarajevo, ${ }^{96}$ appreciated how the Austro-Hungarian occupation had improved the conditions for and the safety of traveling, which had led to a rising tide of tourists to the south - a still little known area of "our empire," attractive for its nature and the inhabitants' costumes and poetic way of life. ${ }^{97}$ The conditions are so good, he argued, that it was safe "even for ladies" to travel there. ${ }^{98}$

94 Obst, II. studijní výprava, 11. In 1912, a popular Czech magazine called Máj reported on a lecture about traveling in Bosnia-Herzegovina that was given in Prague by the director of the Ilidža Spa near Sarajevo, Julius Pojman, author of a German-language guide to BosniaHerzegovina. The report noted the growing interest in this region among Czechs at the time and mentioned that the lecture was well-received by the audience, who were hardly able to fit in Žofín Hall; such an interest was an encouragement for the organizers who were just preparing a new guide to Bosnia-Herzegovina. According to the report, the event showed that there was fertile soil in Czech society for widening touristic activities in Bosnia-Herzegovina and that the official circles in Bosnia-Herzegovina understood the importance of similar efforts. “O cestování v Bosně a Hercegovině," Máj, February 9, 1912, $250-51$.

95 Ferdinand Velc, Průvodce Bosnou a Hercegovinou (Prague: Klub českých turistů, 1907); Vincenc Šindelář, Průvodce Bosnou a Hercegovinou (Prague: Jos. Uher, 1912); Dalmacie $s$ Terstem, Istrií, s pobřežím chorvatským a výletem do Cetyně a Bosna s Hercegovinou (Prague: Čeněk Šulc, n.d., ca. 1913).

96 Velc was mentioned in Buchar's travel account from 1898 (Buchar, První výlet, 63) and he himself wrote a brief account of the trip, which was published in the journal of Czech tourists in 1897 (Velc, "Sarajevo").

97 Velc, Prưvodce, III. The author recommended that travelers visit local people, who were hospitable, in order to benefit from their knowledge and to avoid paying more than necessary, and that they should always knock before entering a "Turkish house" so the women could hide. Velc, Prưvodce, $1-2$. 


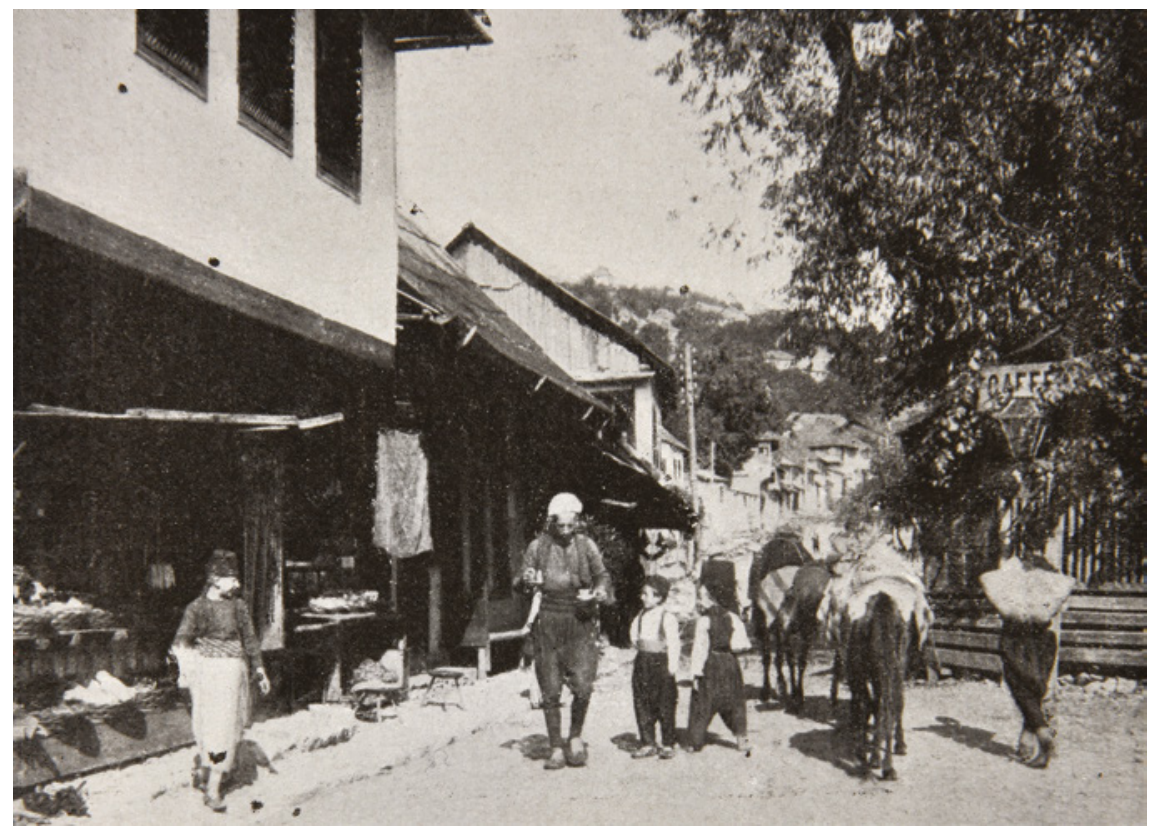

FIGURE 3 "Sarajevo: Z turecké čtvrti" (Sarajevo: From the Turkish Neighborhood), photograph from Průvodce Bosnou a Hercegovinou (A Guide to Bosnia and Herzegovina) by Ferdinand Velc, 1907

A guidebook that explored both Bosnia-Herzegovina and Dalmatia, published in 1913, professed specifically to be aimed at enhancing "Slavic solidarity." 99 Like Velc's book, it emphasized that traveling had become safe and comfortable, even though Bosnia-Herzegovina had been almost closed to visitors until the occupation. After presenting a brief history of the region, the guide gave travelers detailed advice on where to go on their trip, including current prices for trains or cabs, what to see, and how to shop. It commented very little on the population and its religion(s), but noted that Bosnia-Herzegovina was attractive for its nature and particularly for its "Oriental character."100 This was underscored by the accompanying illustrations: photos of men and women in local costumes, namely Oriental clothes, in front of picturesque "Oriental" houses; one picture of a veiled Muslim woman looks like a coat without a body and is reminiscent of some of the current depictions of women in burqas. ${ }^{101}$

99 Dalmacie s Terstem, [3].

$100 \quad$ Ibid., 111.

101 Ibid., 144. 


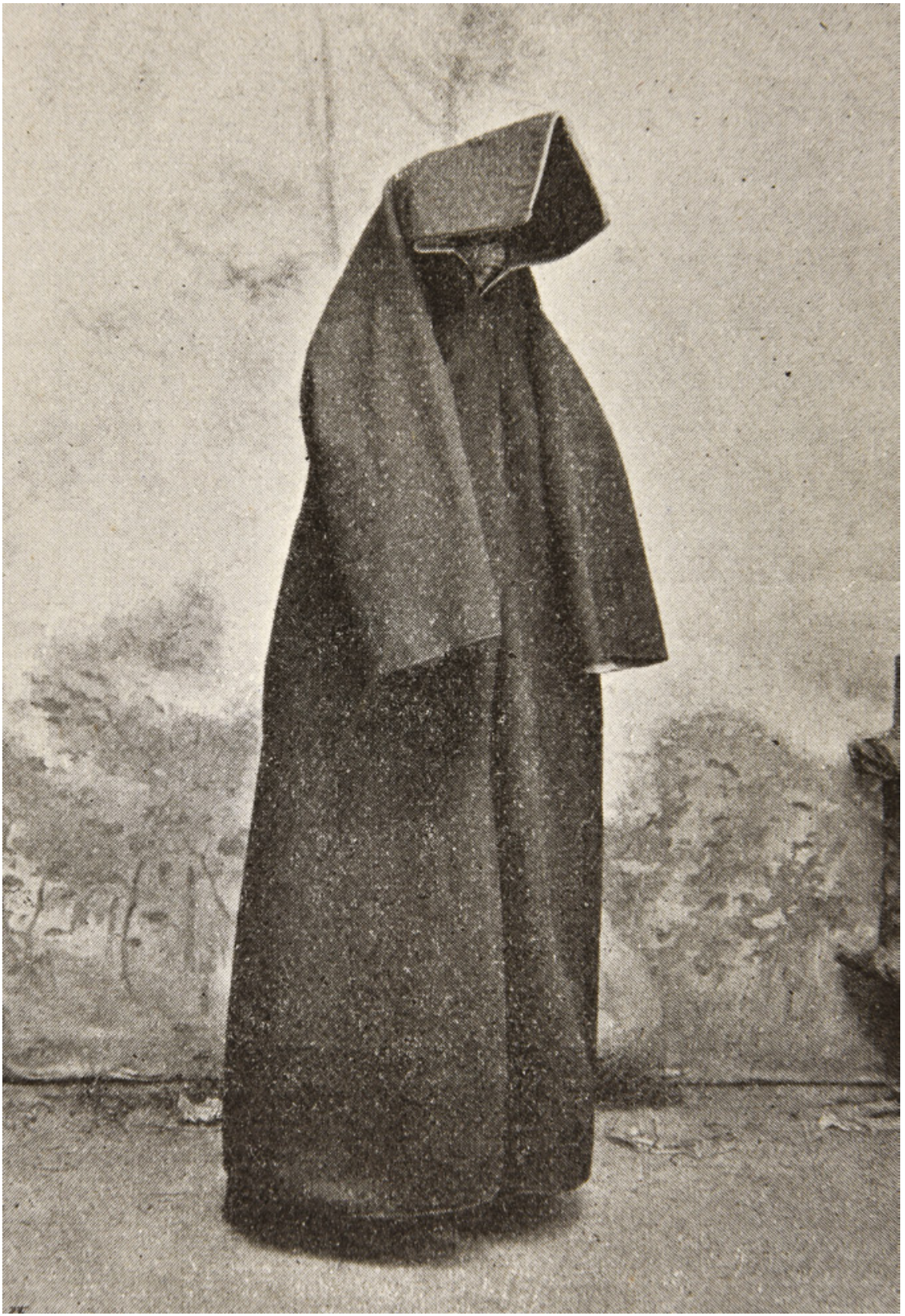

FIGURE 4 "Mohamedánka" (A Muslim Woman), photograph from Dalmacie s Terstem, Istrii, s pobřežím chorvatským a výletem do Cetyně a Bosna s Hercegovinou (Dalmatia and Terst, Istria, the Croatian Coastline and a Trip to Cetinje and Bosnia and Herzegovina), ca. 1913 
While the travelogues and travel guidebooks all stressed Slavic solidarity, both as the aim of the publications and as a fact experienced by the travelers, they were not equally interested in Islam. Buchar, for instance, did not pay much attention to the Islamic sites of Bosnia-Herzegovina, though he mentioned a story (repeated later by Obst) about the grave of a Muslim holy man, whose caretaker prepared a jar of water and a towel every night and claimed that the jar was half empty and the towel wet every morning because the holy man used them for religious ablution. This, Buchar concluded with irony, had to be clear proof that the story was true. ${ }^{102}$ Mostly, the authors connected Islam with the Ottoman past of the provinces, and contrasted it with the present. According to Třeštík, in the 15th century, "the fanatical cry 'Allah!" could be heard throughout the country, and the Austrian occupation in 1878 led to a quickly suppressed uprising of the Mohammedan mob, but now the country was in a cheerful state of revival. Even the dirtiness typical of the Orient had disappeared. ${ }^{103}$ Velc's guidebook highlighted the Oriental character of the towns in Bosnia-Herzegovina and the history of suffering under devastating Turkish rule. Velc mentioned somewhat condescendingly that it was perhaps as a result of this history that Bosnia had not distinguished itself by fighting for any big ideas. The occupation, according to him, marked the start of "the era of European culture"; order and peace were established, and Bosnia-Herzegovina had awoken from a long, heavy slumber. ${ }^{104}$

The Oriental past - once it was safely left behind - could be viewed with some nostalgia, as was the case in the Ottoman Empire. Travelers applauded the modernizing reforms and the growth of modern cities and simultaneously hoped that the "Orientalness" of the region would not disappear. Třeštík both praised the progress achieved under Habsburg rule and admired the exotic Oriental quality of Bosnia-Herzegovina, which he even called the most interesting feature of Sarajevo. ${ }^{105}$ Obst also highlighted the country's Oriental characteristics, which were visible in its architecture from the Ottoman period, its Oriental markets or the jug of a water vendor, decorated with scenes from The Thousand and One Nights. ${ }^{106}$ Compared to travel accounts on the Ottoman Empire, Orientalist stereotypes were certainly less widespread in travel books about Slavic Bosnia-Herzegovina. But they were not entirely absent,

\footnotetext{
102 Buchar, První výlet, $5^{8 .}$

103 Tř̀š́tík, Ku břehưm Adrie, 17.

104 Velc, Průvodce, 2-7.

105 Třeštík, Ku břehưm Adrie, 13.

106 Obst, II. studijní výprava, 57.
} 
and they appeared, for instance, in remarks on Muslims' fatalism or sexual aberrations. ${ }^{107}$

Of particular interest in the Czechs' perception of Bosnia-Herzegovina as Oriental is the way they viewed women, who attracted so much attention among visitors to Istanbul. Gingrich argues that one of the differences between "frontier" and "classic," colonial, Orientalism is that both in its folk and elite versions frontier Orientalism almost exclusively understands the Oriental as a male person, in most cases a single, heterosexual soldier. In contrast to erotic fantasies about Muslim women in classic Orientalism, in its frontier variation women are, according to Gingrich, almost completely ignored, and the only ones who do appear are the female members of the "home" society, threatened by "bad Muslims." 108 Czechs occasionally depicted Bosnian-Herzegovinian women as victims of the Ottoman Turks' lust, sometimes as fighters, but usually as wives and mothers. Muslim women figured in travel literature less as a distinct group and tended to be simply encompassed within the category of "local women" generally; when they were specifically mentioned it was mainly in the context of family. The travelers noted that Muslim families were patriarchal, but that, although women's place was limited to the family and household, conjugal relations were distinguished by mutual respect. ${ }^{109}$ According to Ottův slovník naučný, Muslim women in Bosnia-Herzegovina had more freedom than Ottoman Turkish women: in Bosnia, even elite women wore only light veils allowing their features to be seen, and in Herzegovina, they did not wear veils at all. ${ }^{110}$

Sometimes, however, Czech travelers to Bosnia-Herzegovina employed the same imagery with which others described Ottoman Turkish women. The participants of the trip organized by the KČT in 1897 showed a strong interest in the local harems. Buchar mentioned that Doctor Kecková, one of the first Czech physicians in Bosnia-Herzegovina, helped some of the ladies to satisfy their curiosity about harems by arranging visits for them to prominent Turkish

107 Daneš (Bosna a Hercegovina, 92) said that the Muslims were declinining economically, particularly members of the nobility, who "often indulge in pleasures forbidden by the Koran and fall into moral as well as financial decay." Kuba (Čtení o Bosně a Hercegovině, 232) wrote about the inhabitants of Bosnia-Herzegovina with sympathy but described Sarajevo's mysterious smile as "the fruit perhaps of Oriental fatalism."

108 Gingrich, "Frontier Myths of Orientalism," 120.

109 Holeček, Bosna a Hercegovina, 49-50; Třeštík, Ku břehům Adrie, 22.

110 Ottův slovník naučný (Prague, J. Otto, 1888), 1:433. For a different image of Muslim women in British travel literature see Neval Berber, Unveiling Bosnia-Herzegovina in British Travel Literature (1844-1912) (Pisa: Pisa University Press, 2010), 77. 
households in Mostar. ${ }^{111}$ But most notable was how Velc described the Muslim women of Bosnia-Herzegovina: as lazy and vain, leading an idle life in segregation, their interests limited to the richness of their trousseau, and so dumb that it was impossible to have a conversation with them - in other words, in the same way that some travelers depicted the women of Istanbul. ${ }^{112}$ A different, but no less "Oriental" image of a Slavic Muslim woman appeared in Havlasa's novel Péri, named after its Muslim heroine Zékiye, nicknamed Péri (peri means "fairy" in Turkish). In a plot reminiscent of a medieval romance, the authornarrator runs away with Péri - "the enemy's treasure."13 Wondering about the reason for his attraction to Péri, he explicitly associates Slavic-Muslim with Ottoman-Turkish women: "Before me stood the extraordinary maiden whose strange behavior I mainly explained to myself thus: Ottomanism, a character from the world of the harem. Orient, Orient! Was I right? Was this explanation sufficient? I do not know." 114

While in travel books about the Ottoman Empire women figured mostly as objects, whether of the male gaze or in analyses of their living conditions, in the case of Bosnia-Herzegovina Czech women were in the role of subjects, and they described their own work and travels in the former Ottoman provinces and the provinces' female inhabitants. Bayerová depicted the way of life of local Muslim women with a mixture of caring interest and patronizing despair: "You have no idea how much time I have to make for the Mohammedan women," she complained. She had to prepare every medicine and tea for them, and even had to cook for them if she wanted them to eat something "sensible," instead of their regular dish consisting of a piece of meat boiled with onions in a pot. She felt sorry for the poor children with thin legs and terrible stomachs and felt that, in order to help them, she had to study "their culinary art and try to somewhat improve their things and physiologically to cultivate them..."115

Kecková mentioned also that she helped Muslim women with other issues, not just strictly medical ones. And she was proud to have gained the trust and friendship of the local Muslim women. She attributed her success largely to the fact that the beautiful and intelligent wife of the local mufti had been her patient and was cured by her. This helped to overcome any misgivings about

\footnotetext{
111 Kecková's name is spelled Kheková in the travelogue: "Many individual tourists are grateful to Miss Kheková, MD, the local government physician, because thanks to her kind company they were able to see, apart from numerous places of interest in the city, the way prominent Turkish households are organized as well." Buchar, První výlet, 57.

112 Velc, "Sarajevo," 95.

113 Havlasa, Péri, 73.

114 Ibid., 104.

115 Nečas, Mezi muslimkami, 35.
} 
medical care among even the more conservative Muslim women and the fatalistic attitude they had toward their health; eventually, they started to follow her recommendations. She even managed to get permission to teach several young Muslim women to read, write, and count, which led her to the following conclusion: "I must confess that Muslim women are entirely our equals, with respect even to talent, diligence, and good will; they learn easily and quickly. Only the Koran (the Holy Word) and the immense opposition of Mohammedan men to even the smallest attempt at women's emancipation put insurmountable obstacles in the path of such efforts."116

Vesna Goldsworthy has pointed out that in the late 19th century some of the most interesting British accounts of travel in the Balkans, including BosniaHerzegovina, were written by women. She explained the disproportionate number of women among travelers to the Balkans as due not only to the proximity and safety of the region but especially to the fact that British women could attain the status of "honorary men" when traveling through these patriarchal lands. ${ }^{117}$ Although Czech women also traveled to the South-Slavic regions, their Balkan travels did not necessarily grant them this kind of status, especially if they were traveling in organized tours. Women were wellrepresented among the participants of the trips organized by the Kс̌т and the Teachers' Union; like their male counterparts they seemed to be motivated by their Slavic sympathies, but the closeness and safety of Bosnia-Herzegovina undoubtedly added to the area's attraction. Some women traveled individually, though not necessarily alone, and the published accounts of their experiences contain evidence of the prestige they achieved as travelers. Máša Absolonová rode from Sarajevo to Montenegro in 1912 through an area inhabited mainly by Muslims (Moslemini). On her way, she met crowds of "indigenous" people going to the market in Foča. Her reaction to this scene reveals how a Czech woman positioned herself in relation to the people of Bosnia-Herzegovina and the distance separating the author from the local population, both Christian and Muslim, while discriminating between the Christians and the Muslims or "Turks": The Christian men all enjoyed the comfort of riding a horse, while the women, stumbling along on foot beside their husbands' horses, followed with envy as Absolonová rode her horse. Further on she saw "a whole cavalcade of Turks, headed by a veiled Turkish woman adorned with baubles and trinkets, gold and beads, seated proudly astride a Turkish saddle..."118

116 Kecková, "Z lékařské činnosti," 14.

117 Goldsworthy, "The Balkans," 29-30.

118 Absolonová, "Přes hranice Černé Hory," 305. 
Růžena Svobodová (1868-1920), a respected woman writer, traveled through the South-Slavic regions, including Bosnia-Herzegovina, in $1911 .{ }^{119}$ She was interested in Islam and paid close attention to the faith of the local inhabitants: "I feel respect for everything that I come across and I am concerned not to offend the feelings and sacred customs of the people in prayer," she confessed when she first visited a mosque. "I feel terrible that I should look with my Christian eyes upon conversations with the God of Mohammed, omniscient and all-wise, and despite the efendi's entreaties I retreat toward the door so as not to disturb those who believe in the mystery and try to do right with their prayer... "120 Svobodová, on the one hand, showed humility toward Islam and Muslims' feelings and an affection for the Muslim women she visited in Mostar, extolling their beauty and hospitality. On the other hand, however, she wrote in clichés about the harem, the women's superstitiousness, and their preoccupation with jewelry and having a rich trousseau (which Velc called Muslim women's only interest), and she used other stereotypical images: "Do you know The Thousand and One Nights, I ask. No, she does not, she has never heard of it. I tell her about the book and think to myself: 'Why, you yourself are a Djamile or Safir or Scheherezade."'121

Reference to the stories of The Thousand and One Nights, which is so typical of European - including Czech - travelogues to the Middle East, is evidence that both male and female Czech travelers perceived Bosnia-Herzegovina in general and its Muslims in particular as Oriental. In this respect, the Czechs resembled British travelers and travel writers who "Orientalized" Bosnia-Herzegovina. ${ }^{122}$ This would seem to contradict the claims of Slavic solidarity that the travel accounts and guides emphasized so much. Yet, it was possible to hold both views at the same time, which made for the special attraction of Bosnia-Herzegovina for Czech tourists and distinguished the writings of these tourists from descriptions of trips to the Ottoman Empire: Bosnia-Herzegovina was both Oriental, and thus exotic, and Slavic, and therefore related to the Czechs. The Slavic Muslims differed from other Slavs among other things in

119 When she wrote about the Muslim inhabitants of Mostar and Sarajevo, she switched between references to Turks and Mohammedans; she mostly called women Mohammedans, but sometimes called them Serbian Mohammedans or Turkish, though "of a perfectly Serbian type." Svobodová, Barvy Jugoslavie, 78-83.

120 Ibid., 75 .

121 Ibid., 82.

122 See Omer Hadžiselimović, "The Travelers' Tales: Bosnia and Herzegovina in British Eyes," in At the Gates of the East: British Travel Writers on Bosnia and Herzegovina from the Sixteenth to the Twentieth Centuries, ed. Omer Hadžiselimović (Boulder: East European Monographs, 2001), XXVIII-XXIX. 
that they were seen to be exotic. Their lifestyle and their Ottoman heritage were the source of Bosnia-Herzegovina's Oriental appeal, which Czech tourists could enjoy in the safety of their "home": traveling in their home country and, at the same time, feeling at home among the Slavs.

When Bosnia-Herzegovina was occupied in 1878 , Czech political representatives and the general public accepted the legitimacy of the act, citing the mandate given to Austria-Hungary by the great powers at the Berlin Congress. Imperial policy was supported and the occupation of Bosnia-Herzegovina celebrated in particular by figures connected with the Austro-Hungarian regime, like the conservative Austro-Bohemian politician, legal scholar, and historian Joseph Alexander Helfert. ${ }^{123}$ Judging Austria-Hungary's right to occupy BosniaHerzegovina from the perspective of international law, Josef Trakal, a legal scholar and professor at Charles University, also unequivocally concluded that it had the right to replace the Ottoman Empire in these provinces. ${ }^{124}$ Most Czechs agreed.

A group of Czech members of the imperial and the provincial parliaments made a "jubilee" trip to conduct an inspection of Bosnia-Herzegovina in 1898 . They intended the report on their journey to "be a modest, but hopefully not unwelcome contribution to a glorious chapter in Austrian history ... a festive gift to mark the twentieth anniversary of the Austrian occupation, and an incentive to those who would undertake deeper studies of these flourishing countries that Austria proudly counts as its permanent property."125 The report presented Bosnia-Herzegovina under Ottoman rule as a poor, disorderly and unhappy Oriental country, which the influence of the Austro-Hungarian regime has only started to advance. Yet, the results of the twenty years of Austro-Hungarian occupation were deemed "admirable" and it was claimed Bosnia-Herzegovina could already be considered truly civilized and Sarajevo a

123 In his writings Bosnisches and Die weltgeschichtliche Bedeutung des Wiener Sieges von 1683, he discerned two kinds of inhabitants: the bad Turks and the good Southern Slavs (including Bosnian Muslims). See Heiss and Feichtinger, "Distant Neighbors," $15^{-} 5^{2}$.

124 According to the author, there was no doubt that also the problems arising from the annexation in 1908 would be solved based on the (correct) Austrian view. Josef Trakal, Bosna a Hercegovina po stránce práva mezinárodního (Prague: Bursík a Kohout, 1909), 133 and 188.

125 Dvacet let práce kulturni, [6]. 
modern city. ${ }^{126}$ The authors admitted that the Austro-Hungarian administration had some faults - it was not Slavic and was led by the Hungarian Kállay, with his absolutist tendencies, and it had emerged out of expansionist imperial ambitions. But they noted with satisfaction that, as a result of the occupation, the Slavs of Austria-Hungary had been joined by another 1.5 million of their "fellow-tribesmen." On the whole, the visiting MPs claimed to "have found in Bosnia an administration that is resolute and strict but also performs its work properly and with understanding." ${ }^{127}$

Although the Czechs wished for the unification of the Slavs in BosniaHerzegovina, regardless of their religion, they were divided over which group they supported - the Orthodox Serbs or the Catholic Croatians. The MPs clearly preferred Croatian domination in Bosnia-Herzegovina. Given the tensions between the Serbs and Croats, they considered the Bosnian Muslims, who had just started to show national awareness, an important political factor that would play a decisive role in Bosnia, able to influence the balance of power between groups within the region. ${ }^{128}$ The MPs pushed for Muslims to align themselves with the Catholics, whom they considered to be more open and ready to accept Muslims than the Orthodox Church, which they found stiff and more hostile to Islam. ${ }^{129}$ They argued that relations between Muslims and Christians had become quite open and often friendly, and that perhaps the time would come when it would be asked "whether it would not be right for the Mohammedands to return to the bosom of the Christian Church."130

Toužimský and Holeček evaluated the three groups in Bosnia-Herzegovina according to their level of national awareness and favored the Serbs. Toužimský claimed that the Orthodox Serbs had a stronger sense of national awareness than the Catholics and the Mohammedans, who still identified mainly with their religion. ${ }^{131}$ Holeček considered the Orthodox Serbs by nature to be physically more robust and have a stronger moral foundation; they had not grown tired under the Turkish yoke and had instead rested and gained fresh strength. ${ }^{132} \mathrm{He}$ therefore recommended that the less-educated Muslims follow their Orthodox brothers, who were as conservative as the Muslims in their family life, but otherwise open to progress. ${ }^{133}$

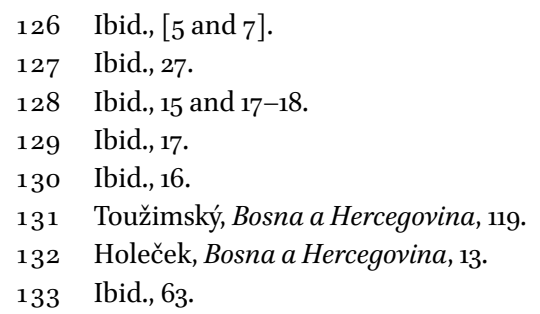


Many who traveled to Bosnia-Herzegovina after the occupation, as we have seen, wrote rather favorably about the impact of Austro-Hungarian rule. The main reason for the approval of the occupation was the perception that the Ottoman Empire's presence in Europe was an aberration. Ottoman rule over the Slavs was considered to have led to stagnation or decay and was identified with backwardness. Toužimský summed up the prevailing opinion with the judgment that both the inhabitants of Bosnia-Herzegovina and their land were backward; centuries and world events had passed without any effect on them. ${ }^{134}$ He contended that Bosnia-Herzegovina's strikingly sparse population was a "natural consequence of the Turkish state economy, which bases and has based all its wisdom on taking wherever there is something to take and wherever it can be taken most easily, regardless of the destruction to all forces of production." 135

The image of backwardness and fanaticism that prevailed under Ottoman rule was contrasted with the progress brought about under the Habsburg administration. Although in 1882 few positive effects of the new regime could yet be noticed, Toužimský pointed out that Bosnia-Herzegovina had only started to awaken from its long medieval stupor. ${ }^{136}$ Jan Třeštík, in his account of the tour of Bosnia-Herzegovina organized by the Кс̌T in 1897, noted that despite what seemed like inertia, Mostar had made striking economic and cultural progress. The population had increased and so had its trust in the new establishment, and this had provided a boost to the development of industry and trade. ${ }^{137}$ Likewise, Sarajevo, "the pearl of Bosnia," he wrote, "finds itself under Austrian rule free from opposition in a pleasurable state of revival."138 $\mathrm{He}$ concluded that thanks to the quiet political conditions, religious tolerance, and improved communications, trade, industry, and culture had developed to an unprecedented extent. A decade later, Daneš maintained that thirty years of Austro-Hungarian rule had brought about more change in Bosnia-Herzegovina than had occurred in the course of centuries in the past and had ushered a backward Oriental country into the reformed Austro-Hungarian present. Two elements, divided in their cultural development by centuries and alien to each other in their world views, had joined together, the effect of which was to shake up "the entire population's primitive Oriental way of life."139

\footnotetext{
134 Toužimský, Bosna a Hercegovina, 125.

135 Ibid., 115.

136 Ibid., 125 .

137 Třeštík, Ku břehům Adrie, 74.

138 Ibid., 20.

139 Daneš, Bosna a Hercegovina, [3].
} 


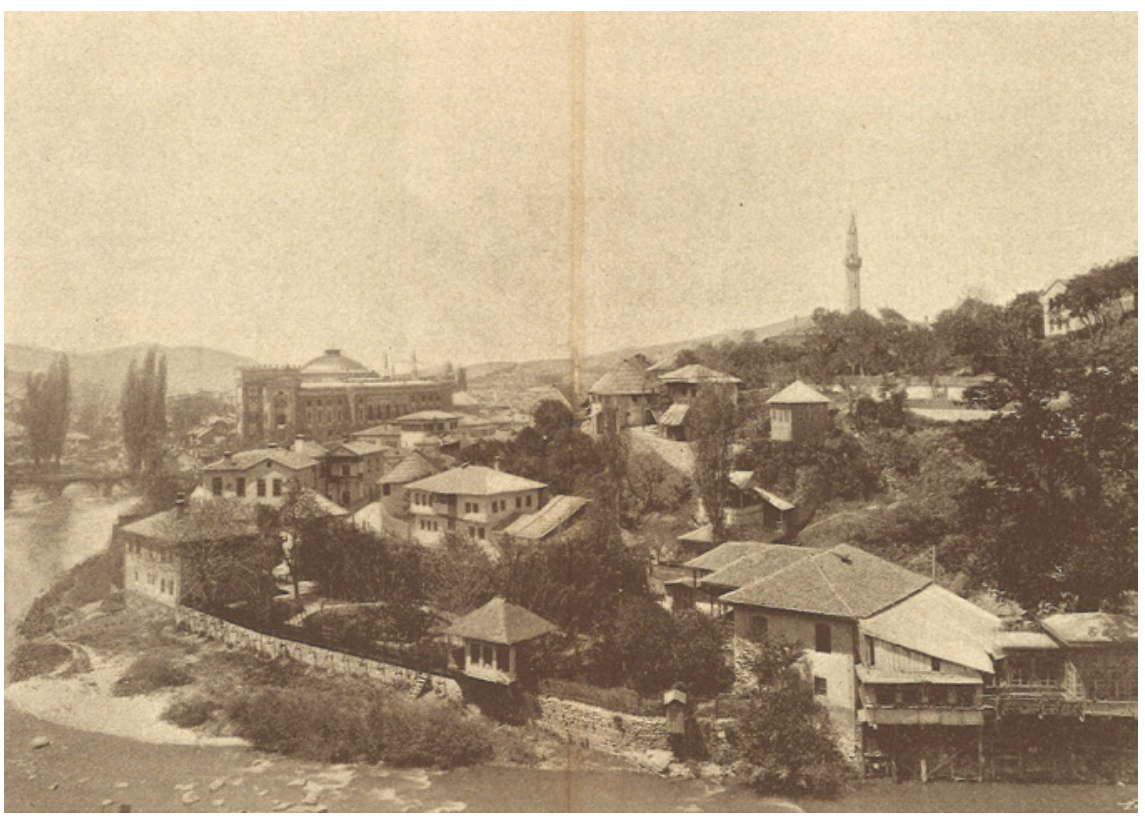

FIgURE 5 "Na Bendbaši v Sarajevě" (Bendbaši in Sarajevo), photograph from Ku břehưm Adrie (Toward the Coasts of Adria) by Jan Třeštík, 1897

Most authors acknowledged the modernizing impact that the AustroHungarian administration's reforms had had on the land and its population, but many criticized them because they lacked a national dimension and did not correspond to the actual needs of the inhabitants of Bosnia-Herzegovina. Moreover, according to them Kállay's autocratic style of rule led local people even to reject positive changes. ${ }^{140}$ The historian Novák aptly summed up the diverse views: Some claim that a country that used to be a theater of endless bloodshed is today a focus of peaceful work, a center from which progress and civilization radiate. Former fighters against the occupation are now the strongest supporters of the government. ${ }^{141}$ At the same time, he continued, dissatisfaction with the regime had increased and thousands of immigrants were leaving the "center of progress and civilization" because they could not live there any more, spiritually or materially. According to Novák, both perspectives on the effects of the reforms had some validity to them. He admitted that Kállay, a great organizer but a despotic ruler, had taken over the country when it was in a state of chaos, resulting from Turkish rule, and he reorganized its

140 Ibid., [4].

141 Novák, "Mezi Adrií a Drávou," 22-23. 
administration from the top down. Novák believed that this absolutism allowed Kállay to introduce "with American speed" changes and progress that were admired by foreigners (and that was their only purpose) and benefitted foreign countries but improved the lot of only a few individuals in the domestic population. Although the administration tried to inculcate the people with "culture" and the benefits of civilization, occasionally doing so with good intentions, it always, according to Novák, used the wrong methods. He argued that the majority of the population, excluded from the benefits of the innovations but burdened by their disadvantages, looked at these changes with fear and hatred..$^{142}$

Consequently, as a number of visitors observed, the local population was opposed to the occupation: even the Czech MPs who looked favorably on Austro-Hungarian rule in Bosnia-Herzegovina pointed out that the people were dissatisfied with the political situation and were far from enthusiastic about "the Švábe" (which is what they called all foreigners) and Habsburg rule. ${ }^{143}$ Others mentioned that the inhabitants of Bosnia-Herzegovina considered the Austro-Hungarian occupation to be even worse than Turkish rule. ${ }^{144}$ Holeček quoted local Serbs, according to whom the occupation's only positive impact was the possible unification of the inhabitants of Bosnia-Herzegovina, who had learned the difference between the Austrian (Švába) and the Turk (Turčin): the former, until they got to know him, for them epitomized education and high-mindedness, the latter embodied stupidity and brutality. But experience had taught them that even the Turčin has some good qualities and no falseness about him, even when he is the enemy. The Švába, in contrast, is false as a friend and as an enemy alike. ${ }^{145}$ Holeček noted that people in some ways remembered Turkish rule in a positive light, because the Turks at least had not wanted them to remain scared and docile when they were asked to pay unfairly high duties, but had wanted them to defend themselves and had even provided them with weapons to do so. ${ }^{146}$

142 Ibid., 22-24.

143 Dvacet let práce kulturní, 9. Šváb means "Swabian," i.e. an inhabitant of a German land, but it also means "cockroach" in Czech. See also Toužimský, Bosna a Hercegovina, 114; Adin Ljuca, "Turci a Švábové, nebo slovanští bratřii? Český pohled na bosenské muslimy v letech 1878-1918," in Pravda, láska a ti na „východě“: Obrazy stredoevropského a východoevropského prostoru z pohledu české společnosti, ed. Mirjam Moravcová, David Svoboda, and František Šístek (Prague: U K F HS, 2006), 122-34.

144 Hořica, Smutné i veselé z Bosny a Hercegoviny, 11-12; Holeček, Bosna a Hercegovina, esp. 9 and 43 .

145 Holeček, Bosna a Hercegovina, 43. Holeček (Bosna a Hercegovina, 49) also notes that even during the war, the Turks showed they could behave in a humane way.

146 Ibid., 65 . 
Some Czech politicians also denounced Habsburg rule in BosniaHerzegovina for being too authoritarian and failing to create conditions for the development of national awareness among the population. ${ }^{147}$ Masaryk's views on Bosnia-Herzegovina reflected his criticism of Austro-Hungarian foreign policy and his pro-Slavic sympathies, which also influenced his opinion on the Ottoman Empire and the Turks, who, as we saw in the first chapter, he primarily viewed as the enemies of the Slavs. He therefore approved of Andrássy's justification of the occupation and believed it should last until the Turks could repay what they owed the Austro-Hungarian Empire and could guarantee that the situation in the provinces would not deteriorate if they came under Ottoman rule again. But he accused the Austro-Hungarian politicians in the prewar period of collaborating with the Turks and hindering the development of the Slavs. ${ }^{148}$ In his speeches in parliament he repeatedly advocated BosniaHerzegovina's autonomy, ${ }^{149}$ and although he appreciated the technical achievements of Austro-Hungarian rule, he denounced the lack of socialpolitical and legal progress. Bosnia-Herzegovina was, for instance, still governed by the old Turkish Islamic law. 150

It is worth underlining that the progress the Czechs advocated was national, rather than political, for which they deemed the inhabitants of BosniaHerzegovina to be insufficiently mature; therefore, they believed that instead of full political rights the people should get more freedom of association, especially with respect to activities benefiting national, or "Slavic," interests. ${ }^{151}$ Czech observers felt that Austro-Hungarian reforms had had a Germanifying effect; since Bosnia and Herzegovina were Slavic countries, whatever

147 See Hladký, "Podíl Čechů," 271-72; Ctibor Nečas, Balkán a česká politika: Pronikání rakousko-uherského imperialismu na Balkán a česká buržoazni politika (Brno: Univerzita J.E. Purkyně, 1972), 81-92.

148 Masaryk, Rakouskázahraničnípolitika, 8.

149 Ibid., 7. Similarly, he noted that most of the criticism of the annexation of 1908 did not concern Austria-Hungary's right to Bosnia-Herzegovina, but the way it was annexed (Masaryk, Rakouská zahraniční politika, 6). Although the reason given for the annexation was the Young Turk constitution in 1908, this, according to Masaryk, did not justify the annexation as the Ottoman constitution of 1876 was never officially abolished, so AustriaHungary could have introduced a constitutional regime in Bosnia-Herzegovina after 1878 had it wished to do so. He wrote that, moreover, the annexation was not permissible without the approval of the people of Bosnia-Herzegovina. He argued that it is wrong to claim that the people are not mature enough to make such a decision - if they are mature enough to pay taxes and serve in the army, they should also be allowed to decide about their fate. (Masaryk, Rakouská zahraniční politika, 41-42).

$150 \quad$ Ibid., 51.

$15^{1}$ Dvacet let práce kulturní, 27. 
violated their Slavic character was detrimental to them and contrary to Czech preferences. ${ }^{152}$

Although many Czechs criticized some aspects of the Austro-Hungarian presence in Bosnia-Herzegovina, only a few opposed the occupation as such. Most notable among them was Josef Holeček, who compared Bosnia-Herzegovina under Austro-Hungarian rule to neighboring Montenegro and noted the ubiquitous military and police control. ${ }^{153}$ According to him, the attempts at modernization had brought about the dissolution of the original culture and a physical degeneration of the local population. He cited as an example the Herzegovinian breed of horses, which, as a result of the occupation, has been mixed with other breeds and become enfeebled. Similarly, the population had grown weaker, shorter, and more pallid, with a "decrease of the original dark race all over the Balkans," the result both of the indigenous population's sexual contact with the newcomers and their moral contamination, leading to decay. ${ }^{154}$

Others were less critical of the fact of the occupation, but condemned the colonizing efforts of "non-Slavic" elements, noting that Bosnia-Herzegovina was "becoming the trophy of political and trade adventurers who consider it a colony for their interests and enrichment."155 "Non-Slavic," however, was the key word: most Czechs concerned with Bosnia-Herzegovina saw nothing wrong with the colonial enterprise, if the economic, trade, and financial activities were being carried out by Czechs.

\section{$4 \quad$ Czech Colonial Ambitions}

The idea of colonization was certainly not foreign to the Czechs. Emil Holub, one of the most famous Czech professional explorers, mentioned among the main goals of his arduous explorations in Africa an attempt "to find land on which the poor and hard-working families of my countrymen could settle in

\footnotetext{
$15^{2}$ Daneš, Bosna a Hercegovina, 4.

153 Holeček, Bosna a Hercegovina, 33-39. Kuba (Čtení o Bosně a Hercegovině, 66-67) also described the impact of the occupation on the decline of local crafts.

154 Holeček, Bosna a Hercegovina, 7-10. Holeček responded negatively to the annexation of Bosnia-Herzegovina in 1908, repeating many of his earlier arguments against AustroHungarian rule. See František Šístek, "Josef Holeček: Kronikář hercegovského povstání a kritik okupace Bosny a Hercegoviny," in Bosna 1878-2008: Sborník př́spěvků z konference konané ve dnech 29.-30. května $2008 v$ Ústí nad Labem (Ústí nad Labem: Ústav slovanskogermánských studií FF UJEP, 2009), 142.

155 Daneš, Bosna a Hercegovina, esp. 159.
} 
the African regions for their own profit and the benefit of the indigenous population." ${ }^{156}$ When Czech authors condemned imperial rule and exploitation in Bosnia-Herzegovina, it was because these actions were not directed by Slavs - it was not criticism of colonialism itself. Even Holeček, who was opposed to the occupation, considered it quite natural that Central European, and particularly Czech, economic, political, and cultural positions in the Balkans should become stronger after the end of Ottoman rule. So far, he complained, opportunities had been taken advantage of mainly by the German, Austrian, and Hungarian elites, and not the Slavs. ${ }^{157}$ Daneš argued that the conditions of Bosnia-Herzegovina were very good for Czech financial enterprises as the local population had been persuaded of the need for a good Slavic bank, which would fight together with local institutions against the power of foreign capital. ${ }^{158}$

The view that "Czech" did not count as "foreign" was held by many Czechs. According to Toužimský, it was essential to introduce the reforms in BosniaHerzegovina through brotherly Czechs, not foreign Germans: "Well, the sole key to the heart of these people is brotherly love. Even if not all at once, it will fully open them up. Without love it is impossible to conquer the heart of the Bosnian-Herzegovinian people."159 Yet, as Daneš argued in the same vein, after the occupation foreign opportunists descended on the country, seeking it as a colony whose resources were theirs for the taking. ${ }^{160}$

An important reason behind the Czechs' criticism of the Austro-Hungarian reforms in Bosnia-Herzegovina was that they allegedly served the interests of German, Hungarian, and Jewish capital. Most authors had some negative remarks to make about the aggressive behavior and "achievements" of these foreigners: Holeček wrote that the pro-German stream, advocating the submission of local culture to the German culture, had strong support from Jews, whose commercial and speculative spirit quickly attracted them to the new territories, "accompanied lightheartedly by the light Magyar cavalry".161 $\mathrm{He}$ claimed that large industry was in German-Jewish hands based in Vienna and Pest and mostly benefited a single group of capitalists who were acquiring a

\footnotetext{
156 Jindřich Dlouhý, ed., Dr. Emil Holub: Africký cestovatel (Prague: Kruh rodáků a př́tel města Holic v Praze, 1947), 32.

157 Holeček, Bosna a Hercegovina, 77-78.

158 Daneš, Bosna a Hercegovina, 165.

159 Toužimský, Bosna a Hercegovina, esp. 125.

160 Daneš, Bosna a Hercegovina, 159-6o.

161 Holeček, Bosna a Hercegovina, 12. Likewise, in Hořica's memoirs (Smutné i veselé z Bosny a Hercegoviny, esp. 13-16), the image of the Turks is more positive than the depiction of the Jews.
} 
monopoly on business in Bosnia-Herzegovina and owned both industrial and commercial enterprises. ${ }^{162}$ Daneš concurred: the profit went to Vienna, Pest, or into the hands of the Germans and Jews, who had only contempt or pity for the local population. ${ }^{163}$ Kállay, Novák asserted, regarded Bosnia and Herzegovina as mere colonies, and the local population as an unwelcome deadweight of natural treasures, which he handed over as loot to a group of Magyar-Jewish and Viennese capitalists, making the population subject to the administration's whims. ${ }^{164}$ The exploited local population had no idea about modern financial economics and with childish carelessness let itself be preyed upon, Daneš argued; only Spanish Jews, the Serbian intelligentsia, a few local Catholics, and even fewer Mohammedans were, according to him, able to profit from the conditions at that time and withstand the influx of foreign capital. ${ }^{165}$ Apart from confirming that Czechs were perhaps more anti-Jewish than they were anti-Turkish in sentiment, these views demonstrate that the Czechs saw Bosnia-Herzegovina under Austro-Hungarian occupation as a land of economic, colonial opportunities, which the Czechs should use for their benefit.

Bosnia-Herzegovina was far from the only target of Czech entrepreneurial ambitions though. Czech architects, engineers, and urbanists were renowned for the various projects they put their hands to in the newly independent Bulgaria, which ranged from bridges and breweries to schools and libraries. ${ }^{166}$ The role of Czechs in Bulgaria reached a peak when a Czech scholar, Konstantin Jireček, became the Bulgarian minister of education. It is no wonder that this period of Bulgarian history is referred to as the time of "Czech cultural

162 Holeček, Bosna a Hercegovina, esp. 12, 72-73, and 77 .

163 Daneš, Bosna a Hercegovina, 125-26.

164 Novák, "Mezi Adrií a Drávou," 22-24.

165 Daneš, Bosna a Hercegovina, 160.

166 See the enlightening TV series Šumné stopy: “Šumné stopy: Bulharsko - Adolf Václav Kolár̆," Česká televize video, 27:05, televised by Česká televize on March 27, 2013, accessed November 20, 2016, http://www.ceskatelevize.cz/porady/10262550261-sumne-stopy/ 212522162350002-bulharsko-adolf-vaclav-kolar/; "Šumné stopy: Bulharsko - Josef Václav Schnitter," Česká televize video, 26:46, televised by Česká televize on April 3, 2013, accessed November 20, 2016, http://www.ceskatelevize.cz/porady/10262550261-sumnestopy/212522162350003-bulharsko-josef-vaclav-schnitter/; "Šumné stopy: Bulharsko Rodina Prošků," Česká televize video, 26:55, televised by Česká televize on March 20, 2013, accessed November 20, 2016, http://www.ceskatelevize.cz/porady/10262550261-sumnestopy/2125221623500o1-bulharsko-rodina-prosku/; "Šumné stopy: Bulharsko - Šipkou do Varny," Česká televize video, 26:58, televised by Česká televize on April 10, 2013, accessed November 20, 2016, http://www.ceskatelevize.cz/porady/10262550261-sumne-stopy/2125 22162350004-bulharsko-sipkou-do-varny/. 
occupation" or "Czech invasion of Bulgaria."167 Similarly, Czechs traveling through Serbia at the turn of the century noted a number of important signs of Czech "assistance" to Serbian development: the beautiful building of the University of Belgrade was designed by the Czech architect Nevole, who, Klaus noted in 1910, "together with General Zach rendered many a service to the young Serbia." 168 In 1903 Raušar described the achievements of the Czechs in Serbia, particularly the families of two entrepreneurs who had arrived in Serbia with no means, but through their diligence and hard work and because they had a mind for business secured themselves a prominent position and considerable renown throughout Serbia. ${ }^{169}$ In the past, Raušar explained, there had been numerous foreign clerks in Serbia: Germans, French, Italians, and Czechs. Only the Czechs and other Slavs were often drawn there out of brotherly love and the desire to learn about the Serbs and their way of life; others wanted to get prestigious and well-paying jobs, and the majority only came to hunt and to fill their own pockets. In the meantime, however, the Serbs had developed their own forces or were at least trying to empower and emancipate themselves from foreigners, who Raušar concluded were decreasing in number. ${ }^{170}$

Raušar's views show that Czechs were aware of the economic or even exploitative nature of many of their countrymen's involvement in the newly independent Slavic countries, although they tried to distinguish it from the activities of other nationals and present it as "brotherly assistance." Hálek, writing about the Serbs in the mid-186os, was even more forthright: "I completely approve of their self-regard [samocit] against foreigners, I approve of it even against the Czechs, who so far have indeed been moving to Serbia for the same reason as all foreigners - to get rich there."171 Half a century later, Masaryk argued that the problem of the Balkans could only be resolved by cultural, not military expansion. While Spanish and Portuguese colonization, relying on military power, had failed, Britain, the United States, France, and newly also Germany and Italy were making successful commercial and cultural encroachments. Masaryk claimed that colonization required strong men, free and enterprising people who could take care of themselves abroad, but Austria encouraged inactivity and weakness; therefore, Germany had been taking over

${ }_{167}$ Jan Rychlík et al., Dějiny Bulharska (Prague: Lidové noviny, 200o), 397. See also Čestmír Amort et al., Dějiny československo-bulharských vztahů (Prague: Academia, 1980), 136-42.

168 Klaus, Do ř́š́s pưlměsíce, 74.

169 Raušar, Na pưdě sopečné, 64-65.

170 Ibid., $65^{-69}$.

171 Hálek, Cestopisy, 257. 
Czech trade positions in the Balkans. ${ }^{172}$ He wrote that the Czechs should not just sit and passively watch how Austrian policy, favoring Young Turks, was hurting Czech industry in the Balkans. ${ }^{173}$ It is obvious that in Masaryk's eyes the lack of colonial activity and ambitions was a Czech weakness.

With the increasing self-sufficiency of the newly independent Balkan countries, Bosnia-Herzegovina had become a more popular place for the Czechs to settle and work. A directory of Czechs living in Sarajevo around 1910, compiled and published by the local Czech expatriate organization Česká Beseda, listed around 2000 Czechs in Sarajevo, whose professions ranged from various state positions to craftsmen and entrepreneurs; among women, the most widespread profession was that of a cook. According to the editors, the directory was not only a valuable tool for Czech industrialists, merchants, bankers, and others who wanted to establish trade contacts in Sarajevo, it was also an important document from the national point of view, as it provided a glimpse at the life of the strong "Czech colony" in this city. ${ }^{174}$ Another booklet published at the same time by a Czech newspaper in Zagreb contained the addresses of Czechs and "especially well-circumstanced compatriots" living in the SouthSlav Balkan countries. ${ }^{175}$ It paid special attention to Bosnia-Herzegovina: the introduction quoted the words of Stjepan Radić, a Croatian politician and correspondent for Czech and other newspapers, who claimed that those who would benefit from the annexation of Bosnia-Herzegovina in 1908 most were the Czechs. No Czech could have summed up the Czechs' position as advanced brothers and entrepreneurs in a colonial setting more bluntly:

The Balkans are for the whole of our empire the promised land of economic influence and expansion that other European powers have sought with so much sacrifice and effort in their colonies. By annexing Bosnia and Herzegovina - a territory as large as the Bohemian Kingdom, but three times more sparsely populated - our empire has become a prominent Balkan state. However, because the Slavs make up a large majority in the Balkans, and also non-Slavs are justifiably mistrustful of or overtly resistant to German encroachment, our empire can quietly assert its economic influence in the Balkans only with the help of its Slavic nations, among whom only the Czechs are at present mature enough to be able to

172 Masaryk, Rakouská zahraniční politika, 29.

173 Ibid., 66.

174 Čechové $v$ Sarajevě dle sčítání lidu v r. 19ı, rev. ed. (Sarajevo: SAmAS, 2012), II.

175 Adresár Čechův jihoslovanských zemích: Charvatsko, Slavonie, Dalmacie, Istrie, Bosna, Hercegovina, Již. Uhry a Srbsko, vol. 2, Adresár slovanských obchodníků (Prague: Administrace "Českého listu” v Záhřebu, 1912), 5. 
fulfill this great task. As soon as the renewed energy of the Czechs is freed up in the near future, once the Czech question is resolved, all of the Czech nation's economic efforts will turn to the Slavic South, toward Croatia and Bosnia in particular, as has long been indicated not only by farsighted individuals, but also by an increasingly strong stream of Czech emigrants and tourists. ${ }^{176}$

In their views on Bosnia-Herzegovina and its Muslims, Czechs occupied the middle ground. They were somewhere between the Austro-Hungarian elites, who saw Bosnia-Herzegovina as a colony and its Muslim population as a potential ally against the emerging "Slavic threat" and the Slavs' national aspirations in the monarchy, and the Balkan Christian Slavs, for whom local Muslims of Slavic origin were (br)others, expected to strengthen the South-Slavic nation once they returned to their Slavic roots. As Slavs and supporters of their southern brothers, the latter view was closer to Czechs' hearts, but at the same time they almost unanimously approved of the Austro-Hungarian occupation of Bosnia-Herzegovina, which they interpreted as liberation from the Ottoman yoke. While there was some criticism of the occupation (for example, by Holeček), it was quite rare. As a result of the heavy-handed administration of the newly occupied territories, its lack of respect for the Slavs' national rights, and the continuing opposition of the local population in Bosnia-Herzegovina to Austro-Hungarian rule, Czech views on the occupation started to diversify. Some Czechs, especially those who represented the empire or held official positions, persisted in their support for the official Austro-Hungarian policy in Bosnia-Herzegovina. Many criticized some aspects of Austro-Hungarian rule, most often its lack of concern for the national development of the Slavs of Bosnia-Herzegovina. And many, while rhetorically and perhaps even sincerely supporting the local population, were eager to take advantage of the opportunities offered in a "backward" Slavic realm that was now attached to the empire.

Czechs viewed the Slavic Muslims with ambivalence. As Slavs they were the Czechs' kin, but because they were associated with the Ottoman Turks, a traditional enemy, anti-Turkish sentiment was also directed at the Muslim Slavs and expressed in images of Muslims as fanatics and as foes of their Christian brothers. Most Czechs who wrote about the Muslims of Bosnia-Herzegovina believed

${ }_{17} 6$ Adresár Čechů, 3. 
they had been influenced by Ottoman-Turkish heritage and were consequently more "backward" than their Christian countrymen. For some Czech travelers to Bosnia-Herzegovina, the Ottoman-Turkish heritage was associated with the perceived fanaticism or fatalism of Muslims, but for most this heritage was a source of exotic appeal. Their accounts show that it was especially the "Oriental" character and Muslim population of Bosnia-Herzegovina that made it so attractive to travelers. In the mainstream Czech view, it was not only the Muslims but all of Bosnia-Herzegovina that was exotic and Oriental, and this could have both negative (backwardness) and positive (exoticism) connotations. It was a tame, local Orient that was safe for tourists - and "even for ladies."

The somewhat paternalistic attitude of the Czechs was not confined to Muslims but was evident also to a greater or lesser extent in their opinions on all the inhabitants of Bosnia-Herzegovina. ${ }^{177}$ In this sense, the difference between the Muslims and Christians was a matter of degree rather than quality. Also, the "civilizing mission," although directed primarily at Muslims, was not limited to them and was interpreted as responding to the "backwardness" of the former Ottoman provinces. The Czechs saw themselves as the vanguard and enlighteners of other Southern Slavs, not just those of Bosnia-Herzegovina. Czech travelers, in particular those who participated in the trips of tourist groups and teachers to various South-Slavic countries, including BosniaHerzegovina, boasted about the esteem in which they were held by the local population; occasionally they also voiced their disappointment at not being treated with sufficient warmth and respect by the Balkan Slavs. ${ }^{178}$ In Absolonovás rendering, the Southern Slavs in Bosnia-Herzegovina were uneducated, lived in primitive dwellings, and ate primitive food; they worked little, but also needed little for their life, and had no feel for business or other duties that would take them away from fighting for their country. Although she acknowledged that this was not the Southern Slavs' fault and their simple life was meaningful, it is clear that she felt superior to the local people, who she believed looked up to the Czechs. ${ }^{179}$

177 For instance, a report on Keckovás achievements in Mostar praised the humanistic activity by which she helped to solve "the woman question among the neglected, forsaken daughters of Eastern Slavdom." "Česká lékařka MDr. Bohuslava Kecková," Ženské listy, November 1898, 217 .

178 Nĕmec (Má cesta, 47-48) complained that while he had envisioned a warm welcome from other Slavs, he saw little interest and even contempt from the Serbs, and the Bulgarians' friendliness was no different from the cordiality they showed to other foreigners, such as Germans, Swedes, or Americans. Klaus (Do řiše pưlměsíce, 40-41) was disappointed by the Serbs' lack of interest in Slavic solidarity.

179 Absolonová, "Přes hranice Černé Hory," 305-7. 
Czech travels to Bosnia-Herzegovina bore some resemblance to the travels of West Europeans to their colonies, but they differed both from traditional colonial journeys and from Czech trips to the Ottoman Empire because, as Slavs, the Czechs saw themselves as ethnically and racially closer to the local population. This is apparent in the depictions of Muslim women in BosniaHerzegovina, in which they were occasionally exoticized like their Ottoman Turkish counterparts, but in most cases were presented through their role in the family, and their families were much like the families of other Slavs. However, the fact that Czech women who wrote about Muslim women mostly viewed them in the same exotic light that men did suggests that arguably "noncolonial" Czech women also participated in the construction of Muslim stereotypes and in the imperial project, just like women representing colonial empires.

After the occupation of Bosnia-Herzegovina, Czechs did not hesitate to take advantage of the opportunities that the newly occupied territories had to offer for business, as a source of employment, and as a place of settlement. This attitude was shared even by the most ardent critics of the occupation, like Holeček, as long as the benefits of the imperial enterprise went to the Czechs, and not to the Germans, Hungarians, or Jews. In contrast to a typical colonial setting, however, the inhabitants were not seen as mere colonial objects. They were the Czechs' Slavic brothers, and while they may have been regarded with some condescension, they were not considered markedly different from or inferior to the Czechs. Czechs clearly had a stronger sense of superiority over the Muslims, whom many continued to associate with the Turks, which prevented them from seeing Slavic Muslims as their true brothers. Yet, the Ottoman heritage was a shortcoming that could be overcome, and not an inborn characteristic, like race.

From this perspective, the Czechs' involvement in Bosnia-Herzegovina might just seem like another venture driven by the Czech entrepreneurial spirit and similar to their pursuits in other parts of Southeastern Europe, a venture that became more attractive as the opportunities for careers and making money in the independent Slavic states began to dwindle. What made the situation in Bosnia-Herzegovina different from other Slavic areas of Southeastern Europe was the fact that the Czechs could and did go there with the support of the empire behind them. Not all the Czechs who settled in, worked with or traveled to Bosnia-Herzegovina were in the service of the state, but their presence in the provinces was made easier by the fact that Bosnia-Herzegovina was ruled by the Austro-Hungarian Empire. The perceived backwardness of the region then gave sufficient justification for various kinds of "civilizing missions." 
That one of the reasons Czechs went to Bosnia-Herzegovina was to improve the lives of the people who had been incorporated into the empire is not inconsistent with their participation in and contribution to the Austro-Hungarian colonial enterprise. The work of the female physicians employed in Bosnia could be viewed in this same way. In 1895 one women's magazine summed up a recently published text by Mrs Kállay, wife of the minister responsible for Bosnia-Herzegovina, as follows: "The first attempt to staff the positions of state doctors by female forces has succeeded wonderfully and it is only to be wished that things continue in this direction and that more female doctors be called up. Apart from purely philanthropic tasks, female doctors also have a deeply important cultural mission, for which they are wholly suited, and they work effectively in this field." ${ }^{180}$ By helping women in Bosnia-Herzegovina, the article concluded, we are substantially advancing "civilization in the Orient."181 Bayerová, and undoubtedly many other Czechs, came to Bosnia-Herzegovina in order to help both themselves and the local people, seeking to improve the population's health and simultaneously to "civilize" them ${ }^{182}$ - just as some West Europeans went to the colonies both to further their own agenda and to uplift the indigeneous population.

180 Vilma de Kallay, "Ženské lékařky v Bosně," Lada, no. 10 (1895): 78.

181 Kallay, "Ženské lékařky," 78.

182 Nečas, Mezi muslimkami, 35. 